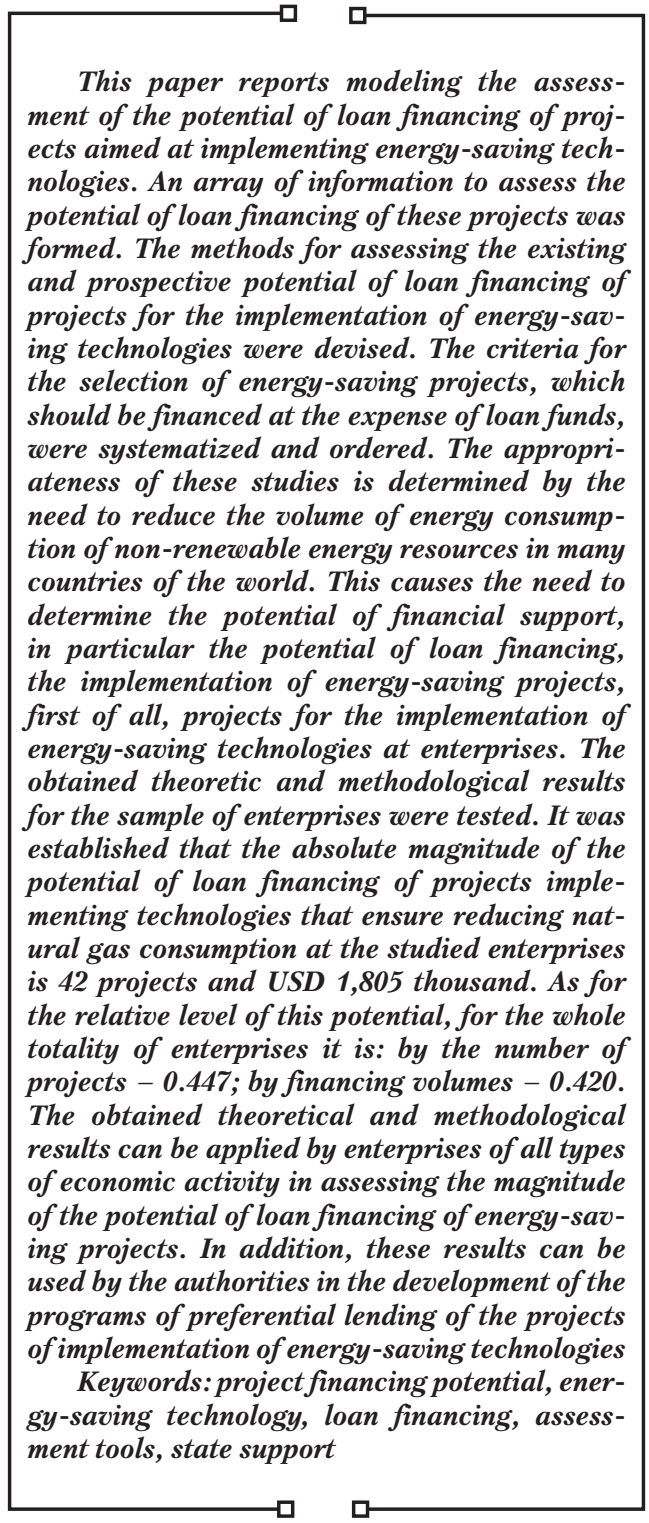

\title{
DEVISING A TOOLSET FOR ASSESSING THE POTENTIAL OF LOAN FINANCING OF PROJECTS AIMED AT IMPLEMENTING ENERGY- SAVING TECHNOLOGIES
}

\author{
Valentyn Lesinskyi \\ Corresponding author \\ $\mathrm{PhD}$, Assistant \\ Department of Radio Engineering and Information Security \\ Yuriy Fedkovych Chernivtsi National University \\ Kotsiubynskoho str., 2, Chernivtsi, Ukraine, 58012 \\ E-mail: lesynsky@chnu.edu.ua \\ Olexandr Yemelyanov \\ Doctor of Economic Sciences, Professor* \\ Oks an Z Zarytska \\ $\mathrm{PhD}$, Associate Professor* \\ Anastasiya S y mak \\ $\mathrm{PhD}$, Associate Professor* \\ Tetiana Petrushka \\ $\mathrm{PhD}$, Associate Professor* \\ *Department of Business Economics and Investment \\ Institute of Economics and Management \\ Lviv Polytechnic National University \\ S. Bandery str., 12, Lviv, Ukraine, 79013
}

Received date 12.07.2021

Accepted date 22.08.2021

Published date 31.08.2021
How to Cite: Lesinskyi, V., Yemelyanov, O., Zarytska, O., Symak, A., Petrushka, T. (2021). Devising a toolset for assessing the potential of loan financing of projects aimed at implementing energy-saving technologies. Eastern-European Journal of Enterprise Technologies, 4 (13 (112)), 15-33. doi: https://doi.org/10.15587/1729-4061.2021.238795

\section{Introduction}

Under conditions of limited volumes of many types of natural resources, governments of countries face the problem of ensuring their sustainable development, in which economic growth takes place without violation of the interests of future generations. Since non-renewable resources include fossil energy resources, in particular, oil and natural gas, ensuring a gradual reduction in the consumption of non-renewable energy resources occupies an important place among the goals of sustainable development of countriesю This is achieved primarily due to increased level of energy efficiency and the transition to the use of alternative energy sources.

However, as the experience of implementing energy-saving measures by enterprises and households shows, there are many obstacles to such implementation. In particular, these obstacles include the lack of necessary information [1] and the lack of financial stimuli for the implementation of ener- gy-saving measures [2]. One of the most significant barriers to improving energy efficiency is often the lack of financial resources necessary for the implementation of energy-saving projects [3]. This is especially true of implementing the projects of energy-saving technological changes at enterprises since these projects often require significant amounts of investment that enterprises do not have at their disposal. At the same time, projects for the introduction of energy-saving technologies at enterprises are important tools for the transition of companies to an energy-saving model of their economic development. This is due to the fact that energy-saving technological changes make it possible to significantly reduce the specific costs of certain types of energy resources for product manufacturing. Accordingly, with an increase in the volumes of its production, if such growth is accompanied by energy-saving technological changes, the total costs of enterprises for the purchase of energy resources will decrease, and profits will increase. In the end, reducing 
specific costs of purchasing energy resources due to the introduction of energy-saving technologies at enterprises can in itself lead to an increase in sales of products due to its increased competitiveness.

The contradiction between the urgent need of enterprises to implement energy-saving technologies and the lack of the necessary amount of financial resources for such implementation can be solved using the principles of loan financing [4]. This concerns, first of all, obtaining bank loans by enterprises. At the same time, their obtaining in a significant number of cases is associated with a certain level of riskiness. This riskiness is due to the fact that enterprises - recipients of loans lack proper volumes of revenues to repay these loans and pay interest for their use. On the other hand, if the current level of energy efficiency at enterprises is low, their implementation of projects of energy-saving technological changes can significantly increase the value of financial outcomes of activities of such enterprises.

Thus, the task of assessing the feasibility of loan financing of projects of energy-saving technological changes is reduced to the implementation of certain procedures by which profitability and riskiness of such projects are matched. These procedures should also be the basis for the development of tools for assessing the potential of financing the implementation of energy-saving technologies at the expense of loan resources. The use of such tools by owners and managers of enterprises will make it possible to obtain a probable assessment of the possibilities of attracting loan resources in order to finance energy-saving technological changes.

From the above, it follows that the issue of developing an effective tool for assessing the potential of loan financing of projects for the implementation of energy-saving technologies is relevant. This relevance, on the one hand, is due to the objective need to intensify energy-saving technological changes in order to increase the level of energy efficiency [5] and transfer to the use of alternative energy sources [6]. On the other hand, there is an urgent need to save financial resources for the implementation of energy-saving projects. Under such conditions, the identification of at least some enterprises with a sufficiently large capacity of loan financing of projects for the implementation of energy-saving technologies will contribute to making decisions on such implementation. This, in turn, will lead to an increase in the scale and speed of energy-saving technological changes in the economy.

\section{Literature review and problem statement}

Assessing the potential of loan financing the projects of the implementation of energy-saving technologies requires the separation from the totality of these projects the ones which are expedient and possible to finance through taking loans. It is also necessary to establish criteria for the selection of these projects. The indicators of crediting effectiveness should be mentioned among the most important criteria.

In general, as noted in paper [7], by effective lending to enterprises, it is advisable to imply the quantitative magnitude of economic, financial, social, environmental, and other consequences obtained through such lending. At the same time, various types of economic consequences of lending to enterprises and the relevant mechanisms that cause these consequences are explored in the literature. It is advisable to highlight three types of such consequences, namely: economic growth of enterprises, an increase of their profits and profitability, as well as an increase in the level of economic risks.

The existence of a significant impact of lending to enterprises on their economic growth is quite convincingly proved in many scientific papers, in particular, in [8]. However, different researchers proposed different criteria for the economic growth of enterprises. In [9], this criterion is an increase in production volumes at enterprises. At the same time, in article [10], it is proposed to consider an increase in income and net assets of companies as economic outcomes of lending to enterprises.

In addition, separate researchers, in particular in [11], evaluated the impact of the volume of lending of companies on profits and profitability of their activities. However, the results of the studies of this impact are ambiguous. Specifically, this concerns the effect of financial leverage, which underlies the mechanism of influence of lending volumes on profits and profitability of enterprises.

Thus, paper [12] points out the positive impact of this effect on the activities of enterprises. In article [13], it was established that there are negative consequences of the financial leverage effect for the development of companies. In the end, the authors of research [14] did not discover a significant impact of this effect on the results of activity of companies. At the same time, some scientists, in particular, the authors of paper [15], indicate the need to optimize the effect of financial leverage.

When it comes to assessing the impact of increasing the volume of lending to enterprises on the riskiness of their activities, at present, there are no generally accepted methods and indicators of such assessment in the scientific literature. It is the lack of generally accepted methods for assessing the riskiness of lending to enterprises that can be the reason why scientists give contradictory assessments to the effect of financial leverage. It should be noted that there are not only direct but also inverse relations between lending volumes and the level of economic risk. As noted in paper [16], bank lending is an important source of funding for firms, however, firms experiencing greater uncertainty are prone to smaller lending volumes. Under such conditions, an increase in the riskiness of companies has a negative impact on the volume of their investments, in particular, in productivity growth [17]. In addition, as shown in paper [18], the level of riskiness of investing in the implementation of resource-saving projects, in particular energy-saving and technological processes, is quite high. Accordingly, the risk of non-repayment of loans taken for an investment in energy-saving measures of enterprises increases, which requires that they should pursue a balanced credit policy.

Thus, scientists separate a significant number of types of economic consequences of lending to enterprises. However, insufficient attention is paid to the selection of those results of the companies that most significantly depend on the volume of received loans. The reason for this may be the complexity of the mechanisms of the impact of lending on a change in the financial and economic performance of enterprises.

Assessment of the potential of loan financing of enterprise development projects, in addition to the effectiveness and riskiness of such financing, should also take into consideration the factor of availability of credit resources.

Attracting credit resources by enterprises, in particular in order to finance energy-saving projects, is often associ- 
ated with the problem of insufficient availability of these resources. Thus, analysis of the activities of small companies in eleven European countries within 2014-2016, which was carried out in article [19], revealed that these companies experienced great difficulties getting access to banking services. As noted in [20], small businesses, especially in countries with transition economies, may face great difficulties in accessing external sources of financing. This is especially true of newly formed companies. Similar results were presented in research [21], which indicates that companies with smaller assets are limited mainly to internal sources of funds while firms with larger assets also attract funds from external sources.

Thus, the size of enterprises, according to scientists, significantly affects the possibility of accessing loans. In relation to other factors that determine the level of availability of loans for companies, as stated in [22], small companies can increase this level if they are able to make a deposit. At the same time, the high profitability of small firms does not have a significant impact on facilitating their receiving a loan [22].

In general, at present, a sufficiently large number of scientific papers is devoted to the issue of assessing the availability of loan resources for enterprises. However, the relationship of this accessibility with the potential of loan financing of the projects that enterprises plan to implement in the future remains beyond the scientists' attention.

As for crediting the projects of the implementation of energy-saving technologies, its availability should be considered in the context of overcoming obstacles that arise on the way to such implementation. In general, the volume of investments in such projects can be quite significant, which under certain conditions will cause the existence of financial barriers to the projects of the implementation of energy-saving technologies [23].

However, the situation in which financial obstacles to the implementation of energy-saving measures at enterprises concern only internal sources of financing is possible, there are principle opportunities for attracting borrowed sources of funds. Then enterprises should evaluate the economic effectiveness and feasibility of such involvement. This also requires an assessment of the expected economic effect of the introduction of energy-saving technologies at enterprises [24]. This effect may be reflected in the magnitude of a decrease in current costs of enterprises due to a decrease in the norms of consumption of certain types of energy resources. However, this magnitude is not deterministic since it largely depends on the level of prices for relevant types of energy resources. For its part, this level can fluctuate significantly over time and is not always easy to predict [25].

In general, as shown in [26], projects for the implementation of energy-saving technological changes can be considered as the tools of adapting enterprises to the growth of prices for corresponding types of energy resources. However, as noted in paper [27], there is a certain range of prices for energy carriers, in which replacing existing technologies with energy-saving technologies will be economically feasible. At the same time, this conclusion is also fair in the case of financing energy-saving projects at the expense of a bank loan. In particular, in [28] it was established that at a significant increase in the price of natural gas, enterprises become unable to repay loans taken to finance such projects (since enterprises will have too little profit left).
Insufficient effectiveness of attracting loans to finance enterprises and/or inadequate level of availability of loan financing may lead to the need for state financial assistance to enterprises. In particular, as noted in [29], such assistance may provide for subsidy-based financing of energy-saving projects. In addition, according to the authors of the paper [30], an important area of state financial support for enterprises is their preferential lending, however, the parameters of such lending should be carefully substantiated.

The conducted review of the literature showed that the issue of developing indicators and methods for assessing the economic efficiency of loan financing of projects for the implementation of energy-saving technologies is not yet definitively resolved. Accordingly, the issue of developing a tool for assessing the potential of such funding remains unresolved. If we consider the causes of this phenomenon, we can name two major ones. Firstly, there is no properly organized and sufficiently complete system of criteria for the selection of those energy-saving projects that enterprises should finance at the expense of borrowed funds. Secondly, the currently existing methodological approaches to assessing the risk of loan financing are insufficiently justified. In addition, the modern scientific literature does not establish a clear link between the levels of efficiency, risk, and availability of lending to enterprises and the magnitude of the potential of loan financing of energy-saving projects. This may be due to the fact that such a statement of the problem has not yet become sufficiently widespread. At the same time, the study of such relations is expedient since it makes it possible to control the potential of loan financing of energy-saving projects.

Thus, given the considerable relevance of the issue of developing a tool for assessing the potential of loan financing of the projects for the implementation of energy-saving technologies, we can conclude that this issue needs further research. In particular, it concerns such tools for assessing the potential of loan financing of energy-saving projects as models of such assessment, its information support, and methods of implementation.

\section{The aim and objectives of the study}

The aim of the present research is to develop a tool for assessing the potential of loan financing of the projects for the implementation of energy-saving technologies at enterprises. This will enable owners and managers of enterprises to get reliable information about their existing and prospective opportunities to implement energy-saving projects at the expense of borrowed funds.

To achieve the set goal, the following tasks were to be solved:

- to model the assessment of the potential of loan financing of the projects for the implementation of energy-saving technologies;

- to form an array of information to assess the potential of loan financing of projects for the implementation of energy-saving technologies;

- to devise the methods for assessing the existing and prospective potential of loan financing of projects for the implementation of energy-saving technologies;

- to test the obtained theoretical and methodological results for the sample of enterprises. 


\section{Materials and methods of research}

The theoretical basis of the study was the studies on ensuring sustainable development of enterprises [31-33], development of their lending policy [34,35], and the rational use of energy resources [36, 37].

For the purpose of empirical analysis, materials of statistical, accounting, and management accounting of a number of enterprises were used. Input information was obtained both based on analyzing the reporting of companies, and through their questionnaire survey.

To generate the formalized criteria for the selection of energy-saving projects, which should be financed through loans, the method of economic and mathematical modeling was applied. The need to use this method was caused by the complexity of the mechanisms of influence of lending to enterprises on the financial and economic performance. That is why the study of these mechanisms requires their preliminary formalization.

In order to organize the criteria for the selection of energy-saving projects, the method of system analysis was used. The need to apply this method is caused by the existence of a significant number of conditions, the fulfillment of which is necessary in order to recognize the feasibility of loan financing of the projects for the implementation of energy-saving technologies at enterprises. These conditions are interrelated and require systematized consideration.

Implementation of empirical research required the use of methods for economic analysis and technical and economic calculations. These techniques make it possible to carry out a detailed assessment of the impact of certain factors on the magnitude of the potential of loan financing of the implementation of projects of energy-saving technologies at enterprises and to quantify this magnitude.

The tabular and graphical methods were used to visualize the results.

When formulating conclusions from the conducted study, we applied the abstract-logical method. This has made it possible to establish the most significant results of the studies, identify the reasons that caused these results, and determine the ways of further study of the studied issues.

\section{Results of studying a toolset for assessing the potential of loan financing of projects for implementing energy- saving technologies}

5. 1. Modeling the assessment of the potential of loan financing of projects for implementing energy-saving technologies

Assessment of the potential of loan financing of projects for the implementation of energy-saving technologies requires, first of all, the formation of an input array of information about such projects. Subsequently, among these projects, one should choose those that should be financed through the use of bank loans and other types of loan sources of funds. Then the potential of loan financing of projects for the implementation of energy-saving technologies can be estimated, in particular, by the amount of investment in the implementation of these projects. However, it is quite a challenge to separate the projects that should be financed through loans among the input array of information about projects of the implementation of energy-saving technologies. Its solution requires the implementation of a multi-step process, the description of which is shown in Fig. 1.

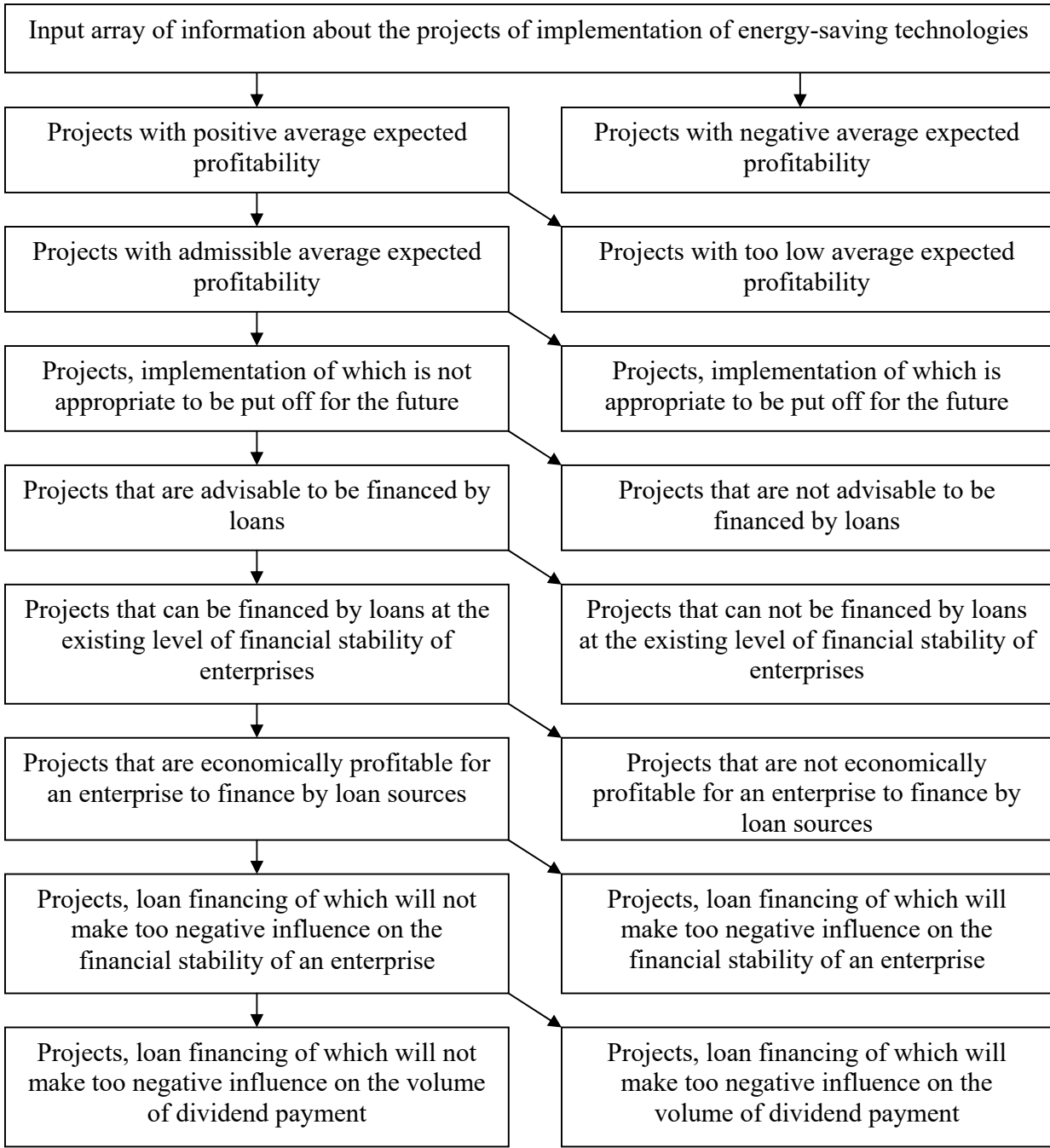

Fig. 1. The process of selection of projects for the implementation of energy-saving technologies, which are appropriate to be financed from borrowed sources of funds 
It is important to distinguish between the absolute and relative magnitudes of the potential of loan financing of the projects for the implementation of energy-saving technologies. As for the absolute magnitudes of this potential, they can be measured by the number of projects that are appropriate to be financed through loans and the amount of such funding. As for assessing the relative level of the specified potential, it can be determined by the share of the projects that should be financed through loans in the total number of the projects under consideration. Another approach to such assessment is to establish the share of investments in projects that are appropriate to be financed by loans, in the total amount of investments in the implementation of the entire totality of the projects under consideration.

Taking into consideration the above, the relative level of the potential of loan financing of the projects of the implementation of energy-saving technologies can be represented by the following two multiplicative models:

$$
I_{p}=\prod_{i=1}^{8} I_{p i}
$$

$$
I_{c}=\prod_{i=1}^{8} I_{c i}
$$

where $I_{p}$ is the relative level of the potential of loan financing of the projects of implementation of energy-saving technologies by the number of projects;

$I_{p 1}, \ldots, I_{p 8}$ are the components of the multiplicative model of the potential of loan financing of the projects of implementation of energy-saving technologies, by the number of projects;

$I_{C}$ is the relative level of the potential of loan financing of the projects of implementation of energy-saving technologies, by the investment volumes;

$I_{c 1}, \ldots, I_{c 8}$ are the components of the multiplicative model of the potential of loan financing of the projects of implementation of energy-saving technologies, by the investment volumes.

The order of calculating the indicators contained in models (1) and (2) is described in Table 1.

It should be noted that the indicators of the need for $C_{i}$ investments, the description of which is given in Table 1 , are influenced by various factors. The way these factors are grouped is shown in Table 2.

Table 1

Indicators contained in multiplicative models of the magnitude of the potential of loan financing of projects for the

\begin{tabular}{|c|c|c|c|c|}
\hline Indicators & $\begin{array}{l}\text { Kinds of } \\
\text { indicators }\end{array}$ & $\begin{array}{l}\text { Designa- } \\
\text { tion of } \\
\text { indicators }\end{array}$ & $\begin{array}{l}\text { Calcu- } \\
\text { lation } \\
\text { formula }\end{array}$ & Designation of indicators contained in formulas \\
\hline 1 & 2 & 3 & 4 & 5 \\
\hline \multirow[b]{2}{*}{$\begin{array}{l}\text { 1. Share of profitable projects } \\
\text { among all projects }\end{array}$} & $\begin{array}{l}\text { By the } \\
\text { number of } \\
\text { projects }\end{array}$ & $I_{p 1}$ & $P_{1} / P$ & $\begin{array}{c}P-\text { the total number of projects for the implementation of ener- } \\
\text { gy-saving technologies at enterprises, units; } \\
P_{1}-\text { the number of projects with positive average profitability, units }\end{array}$ \\
\hline & $\begin{array}{l}\text { By required } \\
\text { investment }\end{array}$ & $I_{c 1}$ & $C_{1} / C$ & $\begin{array}{c}C \text { - the general need for investments to realize the projects for } \\
\text { the implementation of energy-saving technologies at enterpris- } \\
\text { es, monetary units; } \\
C_{1}-\text { the need for investments to realize the projects for the } \\
\text { implementation of energy-saving technologies at enterprises, } \\
\text { monetary units }\end{array}$ \\
\hline \multirow{2}{*}{$\begin{array}{l}\text { 2. Share of projects with permis- } \\
\text { sible average profitability among } \\
\text { profitable projects }\end{array}$} & $\begin{array}{l}\text { By the } \\
\text { number of } \\
\text { projects }\end{array}$ & $I_{p 2}$ & $P_{2} / P_{1}$ & $\begin{array}{l}P_{2}-\text { the number of projects with permissible average profitabil- } \\
\text { ity, units }\end{array}$ \\
\hline & $\begin{array}{l}\text { By required } \\
\text { investment }\end{array}$ & $I_{c 2}$ & $C_{2} / C_{1}$ & $\begin{array}{c}C_{2}-\text { the need for investments to implement the projects with } \\
\text { permissible average profitability, monetary units }\end{array}$ \\
\hline \multirow{2}{*}{$\begin{array}{l}\text { 3. Share of projects, the im- } \\
\text { plementation of which is not } \\
\text { advisable to postpone, among } \\
\text { projects with permissible aver- } \\
\text { age profitability }\end{array}$} & $\begin{array}{l}\text { By the } \\
\text { number of } \\
\text { projects }\end{array}$ & $I_{p 3}$ & $P_{3} / P_{2}$ & $\begin{array}{c}P_{3}-\text { the number of projects, the implementation of which is not } \\
\text { appropriate to postpone, units }\end{array}$ \\
\hline & $\begin{array}{l}\text { By required } \\
\text { investment }\end{array}$ & $I_{c 3}$ & $C_{3} / C_{2}$ & $\begin{array}{l}C_{3} \text { - the need for investments to realize the projects, the implemen- } \\
\text { tation of which is not appropriate to postpone, monetary units }\end{array}$ \\
\hline \multirow{2}{*}{$\begin{array}{l}\text { 4. Share of projects that are ad- } \\
\text { visable to be financed from loan } \\
\text { sources among the projects that } \\
\text { are not advisable to postpone }\end{array}$} & $\begin{array}{l}\text { By the } \\
\text { number of } \\
\text { projects }\end{array}$ & $I_{p 4}$ & $P_{4} / P_{3}$ & $\begin{array}{c}P_{4}-\text { the number of projects that may be advisable to finance } \\
\text { from loan sources, units }\end{array}$ \\
\hline & $\begin{array}{l}\text { By required } \\
\text { investment }\end{array}$ & $I_{c 4}$ & $C_{4} / C_{3}$ & $\begin{array}{l}C_{4}-\text { the need for investments to implement the projects that } \\
\text { may be expedient to finance from loan sources, monetary units }\end{array}$ \\
\hline \multirow{2}{*}{$\begin{array}{l}\text { 5. Share of projects, for the } \\
\text { financing of which enterprises } \\
\text { are able to attract loans at the } \\
\text { existing level of their financial } \\
\text { stability, among projects that } \\
\text { may be appropriate to finance } \\
\text { from loan sources }\end{array}$} & $\begin{array}{l}\text { By the } \\
\text { number of } \\
\text { projects }\end{array}$ & $I_{p 5}$ & $P_{5} / P_{4}$ & $\begin{array}{l}P_{5}-\text { the number of projects, for the financing of which enter- } \\
\text { prises are capable to attract loans at the existing level of their } \\
\text { financial stability, units }\end{array}$ \\
\hline & $\begin{array}{l}\text { By required } \\
\text { investment }\end{array}$ & $I_{c 5}$ & $C_{5} / C_{4}$ & $\begin{array}{l}C_{5} \text { - the need for investments for the implementation of projects, } \\
\text { for the financing of which enterprises are capable to attract loans } \\
\text { at the existing level of their financial stability, monetary units }\end{array}$ \\
\hline \multirow{2}{*}{$\begin{array}{l}\text { 6. Share of projects, which are } \\
\text { economically profitable for } \\
\text { enterprises to finance from } \\
\text { loan sources, among projects to } \\
\text { finance which enterprises can } \\
\text { attract loans at the existing level } \\
\text { of their financial stability }\end{array}$} & $\begin{array}{l}\text { By the } \\
\text { number of } \\
\text { projects }\end{array}$ & $I_{p 6}$ & $P_{6} / P_{5}$ & $\begin{array}{l}P_{6}-\text { the number of projects, which are economically profitable } \\
\text { for enterprises to finance from loan sources, units }\end{array}$ \\
\hline & $\begin{array}{l}\text { By required } \\
\text { investment }\end{array}$ & $I_{c 6}$ & $C_{6} / C_{5}$ & $\begin{array}{l}C_{6} \text { - the need for investments for the implementation of projects, } \\
\text { financing of which from loan sources is economically profitable } \\
\text { for enterprises, monetary units }\end{array}$ \\
\hline
\end{tabular}
implementation of energy-saving technologies at enterprises 
Continuation of Table 1

\begin{tabular}{|c|c|c|c|c|}
\hline 1 & 2 & 3 & 4 & 5 \\
\hline \multirow{2}{*}{$\begin{array}{l}\text { 7. Share of projects, financing of } \\
\text { which by loans will not have a too } \\
\text { negative impact on changing the } \\
\text { financial stability of enterprises, } \\
\text { among projects, financing of which } \\
\text { from loan sources is economically } \\
\text { profitable for enterprises }\end{array}$} & $\begin{array}{l}\text { By the } \\
\text { number of } \\
\text { projects }\end{array}$ & $I_{p 7}$ & $P_{7} / P_{6}$ & $\begin{array}{l}P_{7}-\text { the number of projects financing of which by loans will not } \\
\text { have a too negative impact on changing the financial stability of } \\
\text { enterprises, units }\end{array}$ \\
\hline & $\begin{array}{l}\text { By required } \\
\text { investment }\end{array}$ & $I_{C 7}$ & $C_{7} / C_{6}$ & $\begin{array}{l}C_{7} \text { - the need for investments for the implementation of projects, } \\
\text { financing of which by loans will not have a too negative impact on } \\
\text { a change in the financial stability of enterprises, monetary units }\end{array}$ \\
\hline \multirow{2}{*}{$\begin{array}{c}\text { 8. Share of projects financing } \\
\text { of which by loans will not have } \\
\text { a too negative impact on the } \\
\text { volume of dividend payments } \\
\text { of enterprises, among projects, } \\
\text { loan financing of which will not } \\
\text { have a too negative impact on } \\
\text { changing the financial stability } \\
\text { of enterprises }\end{array}$} & $\begin{array}{l}\text { By the } \\
\text { number of } \\
\text { projects }\end{array}$ & $I_{p 8}$ & $P_{8} / P_{7}$ & $\begin{array}{l}P_{8} \text { - the number of projects, financing of which by loans will not } \\
\text { have a too negative impact on the volume of dividend payments } \\
\text { of enterprises, units }\end{array}$ \\
\hline & $\begin{array}{l}\text { By required } \\
\text { investment }\end{array}$ & $I_{c 8}$ & $C_{8} / C_{7}$ & $\begin{array}{l}C_{8} \text { - the need for investments for the implementation of projects, } \\
\text { loan financing of which will not have a too negative impact on the } \\
\text { volume of dividend payments of enterprises, monetary units }\end{array}$ \\
\hline
\end{tabular}

Table 2

Factors influencing the need for investment in projects for the implementation of energy-saving technologies at enterprises

\begin{tabular}{|c|c|c|}
\hline Groups of factors & Names of factors & $\begin{array}{c}\text { Designation } \\
\text { of factors }\end{array}$ \\
\hline \multirow{6}{*}{$\begin{array}{l}\text { 1. Factors that determine } \\
\text { the level of economic } \\
\text { effectiveness of the imple- } \\
\text { mentation of projects for } \\
\text { the implementation of en- } \\
\text { ergy-saving technologies }\end{array}$} & 1. 1. The required amount of investment in the implementation of each project & F.1.1 \\
\hline & $\begin{array}{l}\text { 1. 2. Physical volumes of the economy of energy resources as a result of the implementation of } \\
\text { each project }\end{array}$ & F.1.2 \\
\hline & $\begin{array}{l}\text { 1. 3. The average expected level of prices for energy resources, the economy of which is envis- } \\
\text { aged for each project }\end{array}$ & F.1.3 \\
\hline & $\begin{array}{l}\text { 1. 4. The expected average magnitude of additional current costs caused by the implementation } \\
\text { of each project }\end{array}$ & F.1.4 \\
\hline & 1.5. Norm of investment profitability & F.1.5 \\
\hline & 1. 6. Level of the riskiness of the implementation of each project & F.1.6 \\
\hline \multirow{4}{*}{$\begin{array}{l}\text { 2. Factors that determine } \\
\text { the level of economic } \\
\text { effectiveness of using } \\
\text { existing technological } \\
\text { processes at enterprises, } \\
\text { the replacement of which } \\
\text { is considered } \\
\end{array}$} & 2. 1. Expected effective term of operation of existing technological processes at enterprises & F.2.1 \\
\hline & $\begin{array}{l}\text { 2. 2. Predicted distribution by years of net cash flow from the operation of existing technologi- } \\
\text { cal processes }\end{array}$ & F.2.2 \\
\hline & $\begin{array}{l}\text { 2.3. Predictive change over time in the need of investment in replacing existing technological } \\
\text { processes with energy-saving ones }\end{array}$ & F.2.3 \\
\hline & 2. 4. Discount rate & F.2.4 \\
\hline \multirow{5}{*}{$\begin{array}{l}\text { 3. Factors that determine } \\
\text { the economic effectiveness } \\
\text { of attracting borrowed } \\
\text { funds in order to finance } \\
\text { projects for the implemen- } \\
\text { tation of energy-saving } \\
\text { technologies at enterprises }\end{array}$} & $\begin{array}{l}\text { 3. 1. Availability of the mechanisms of financial support of the realization of projects for } \\
\text { implementing energy-saving technologies, which are more attractive for enterprises than loan } \\
\text { financing (budget subsidies, sponsorship, grants, etc.) }\end{array}$ & F.3.1 \\
\hline & 3. 2. Average interest rate by loans & F.3.2 \\
\hline & 3. 3. Loan availability & F.3.3 \\
\hline & 3.4. Maximum terms for which loans can be taken & F.3.4 \\
\hline & $\begin{array}{l}\text { 3. 5. Availability of state programs to support enterprises that expect to receive loans to finance } \\
\text { energy-saving projects }\end{array}$ & F.3.5 \\
\hline \multirow{5}{*}{$\begin{array}{l}\text { 4. Factors that deter- } \\
\text { mine the current level of } \\
\text { financial stability of those } \\
\text { enterprises that plan to } \\
\text { realize projects for the } \\
\text { implementation of ener- } \\
\text { gy-saving technologies } \\
\end{array}$} & 4.1. Average expected magnitude of profit before paying interest on loans and income taxes & F.4.1 \\
\hline & $\begin{array}{l}\text { 4. 2. Level of fluctuations in the expected magnitude of profit before paying interest on loans } \\
\text { and taxes on profits }\end{array}$ & F.4.2 \\
\hline & 4.3. Available volume of loan capital & F.4.3 \\
\hline & 4.4. Structure of borrowed capital by terms of repayment of loans & F.4.4 \\
\hline & 4. 5. Level of interest rates on previously taken loans & F.4.5 \\
\hline \multirow{5}{*}{$\begin{array}{l}\text { 5. Requirements of owners } \\
\text { of enterprises planning } \\
\text { to realize projects for the } \\
\text { implementation of ener- } \\
\text { gy-saving technologies } \\
\text { for the parameters of loan } \\
\text { financing }\end{array}$} & 5. 1. Maximum possible level of probability that taking a loan will be worthwhile & F.5.1 \\
\hline & $\begin{array}{l}\text { 5. 2. The minimum permissible level of the ratio between the average return on investment in } \\
\text { projects and interest rate }\end{array}$ & F.5.2 \\
\hline & 5. 3. Maximum admissible level of probability of bankruptcy & F.5.3 \\
\hline & $\begin{array}{l}\text { 5. 4. The minimum permissible amount of dividend payments and their distribution by years of } \\
\text { the forecast period }\end{array}$ & F.5.4 \\
\hline & $\begin{array}{l}\text { 5. 5. The maximum permissible level of probability that as a result of taking a loan, the company will } \\
\text { not be able to satisfy the owners' conditions regarding the volumes and terms of dividend payments }\end{array}$ & F.5.5 \\
\hline
\end{tabular}

The factors listed in Table 2 also have an indirect impact on the relative level of the potential of loan financing of projects for the implementation of energy-saving technologies in terms of volumes of investments. The model of such influence is shown in Fig. 2. 


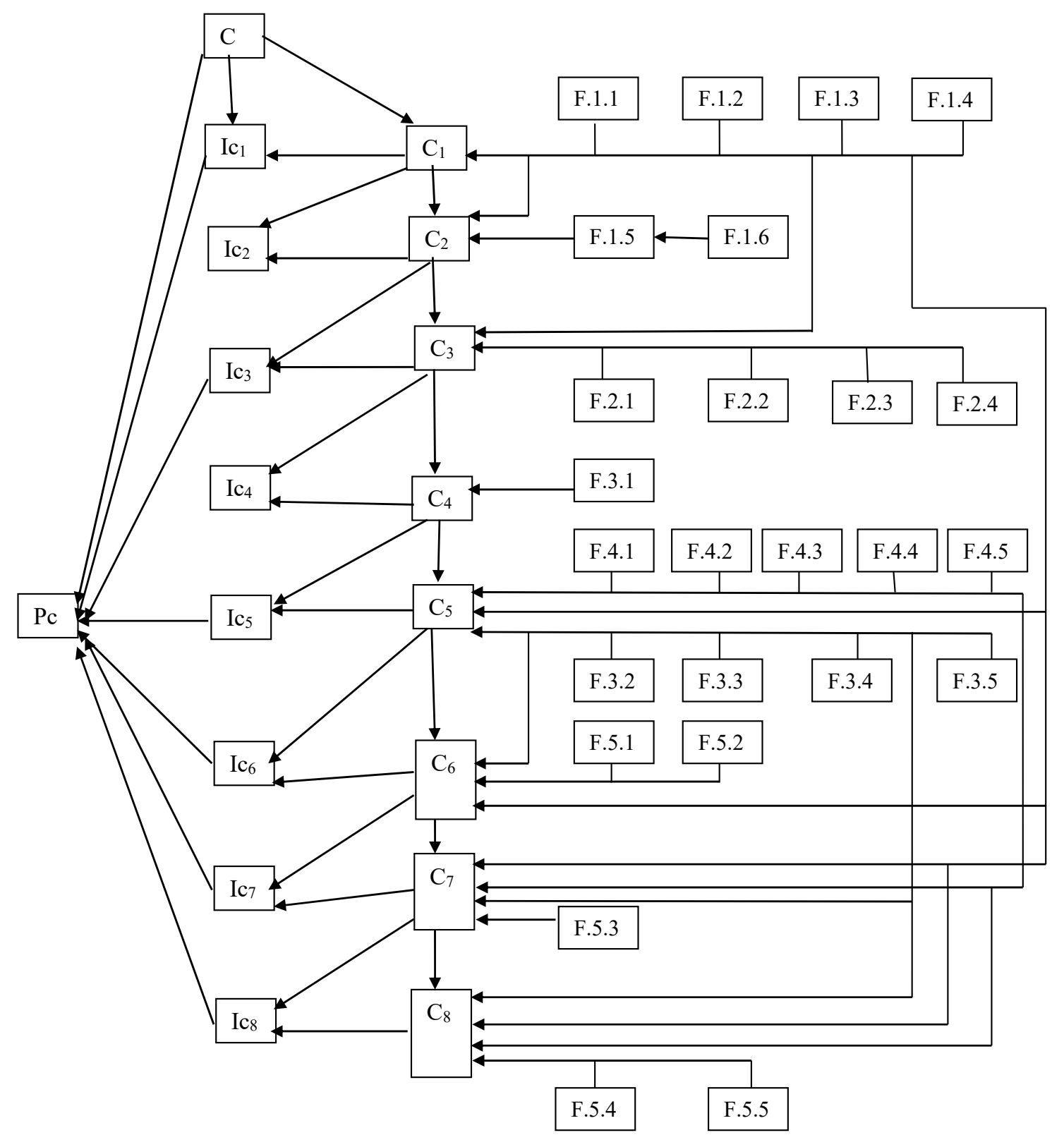

Fig. 2. Model of influence of factors on the relative level of potential of loan financing of projects of implementation of energysaving technologies at enterprises

The use of the model presented in Fig. 2 makes it possible to identify reserves for the growth of the potential of loan financing of projects for the implementation of energy-saving technologies. To this end, it is necessary to influence the corresponding factors that indirectly determine this potential in order to increase the need for investments in the implementation of energy-saving projects. At the same time, each stage of the formation of such a need should be considered separately. Accordingly, it is possible to highlight the existing (existing currently) and prospective potential of loan financing of projects for the implementation of energy-saving technologies. As for the prospective potential, it is formed in the process of improving lending conditions and enhancing the competence of enterprise employees in matters of loan financing of energy-saving projects.
5. 2. Formation of an array of information to assess the potential of loan financing of projects for implementing energy-saving technologies

Assessment of the potential of loan financing of projects of implementation of energy-saving technologies at enterprises requires a wide range of incoming (primary) information. This information can be divided into several units (Table 3). In particular, it is worth highlighting information about: an energy-saving project, the expected financial outcome of an enterprise after the project implementation, lending conditions, preferences of owners and managers, as well as other information.

In particular, one of the main components of input information that is necessary to assess the potential of loan financing of projects for the implementation of energy-saving technologies is the function of distribution of probabilities of 
financial outcomes. Two main types of such functions should be identified - those describing financial outcomes of a project and those that describe financial outcomes of an enterprise after the project implementation. At the same time, this work considers two ways to present these functions: continuous and discrete. The continuous method is based on the approximation of the probability distribution graph by polygonal lines. This method should be used when it is necessary to assess the probability that the financial outcomes will not exceed their predefined value. As for the discrete way of presenting the function of distribution of financial outcomes, it is more expedient to use it when assessing the riskiness of projects.

Table 3

Grouping of incoming information necessary to assess the potential of loan financing of projects for the implementation of energy-saving technologies

\begin{tabular}{|c|c|}
\hline Units of information & Main content of units of information \\
\hline $\begin{array}{l}\text { 1. Information } \\
\text { about an ener- } \\
\text { gy-saving project }\end{array}$ & $\begin{array}{l}\text { Required investments in the project, mathe- } \\
\text { matical expectation of income and profits un- } \\
\text { der the project, the function of distribution } \\
\text { of probabilities of financial outcomes under } \\
\text { the project, the level of riskiness of project } \\
\text { implementation, etc. }\end{array}$ \\
\hline $\begin{array}{l}\text { 2. Information on } \\
\text { the expected finan- } \\
\text { cial outcomes of an } \\
\text { enterprise after the } \\
\text { project implemen- } \\
\text { tation }\end{array}$ & $\begin{array}{l}\text { The mathematical expectation of financial } \\
\text { outcomes of the enterprise's activity after the } \\
\text { project implementation, the function of dis- } \\
\text { tribution of probabilities of these results, etc. }\end{array}$ \\
\hline $\begin{array}{l}\text { 3. Information on } \\
\text { lending conditions }\end{array}$ & $\begin{array}{l}\text { Loan rates, loan terms, need and volume of de- } \\
\text { posit, repayment schedules for taken loans, etc. }\end{array}$ \\
\hline $\begin{array}{l}\text { 4. Information on } \\
\text { preferences of own- } \\
\text { ers and managers }\end{array}$ & $\begin{array}{l}\text { The permissible level of project profitability, } \\
\text { permissible probability of unsuccessful proj- } \\
\text { ect implementation, permissible probability } \\
\text { of bankruptcy of an enterprise, etc. }\end{array}$ \\
\hline $\begin{array}{l}\text { 5. Other informa- } \\
\text { tion }\end{array}$ & $\begin{array}{l}\text { Information about technological processes that } \\
\text { are supposed to be replaced with energy-saving } \\
\text { technologies, information about alternative } \\
\text { ways of financial support for the implementa- } \\
\text { tion of an energy-saving project, etc. }\end{array}$ \\
\hline
\end{tabular}

In particular, in the case of constructing a continuous function of distribution of probabilities of financial outcomes for a project, one must first establish the final set of values of probability and the corresponding magnitude of the financial outcome for the project before paying interest on the loan. For this purpose, the expert survey method can be used. Then the function of distribution of probabilities of financial outcomes under the project of implementation of energy-saving technologies will have the following formalized form:

$$
\begin{aligned}
& P_{r p}\left(R_{p}\right)=
\end{aligned}
$$

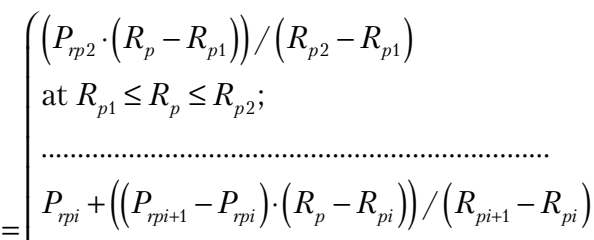

$$
\begin{aligned}
& \text { at } R_{p i} \leq R_{p} \leq R_{p i+1} \text {; } \\
& P_{r p n-1}+\left(\left(1-P_{r p n-1}\right) \cdot\left(R_{p}-R_{p n-1}\right)\right) /\left(R_{p n}-R_{p n-1}\right) \\
& \text { at } R_{p n-1} \leq R_{p} \leq R_{p n} \text {, }
\end{aligned}
$$

where $P_{r p}$ is the probability that the magnitude of the financial outcome under the project before payment of interest on the loan will not exceed $R_{p}$;

$R_{p}$ is the variable magnitude that characterizes the magnitude of the financial outcome under project before payment of interest on a loan, monetary units;

$P_{r p i}$ is the probability that the magnitude of the financial outcome under project before payment of interest on the loan will not exceed $R_{p i}$;

$n$ is the number of initial values of probability and corresponding magnitude of the financial outcome under project before payment of loan interest.

In turn, in order to plot the continuous function of distribution of probabilities of financial outcomes of an enterprise after the implementation of an energy-saving project, the final set of values of probability and the corresponding magnitude of financial outcomes should be constructed first. These results can be the magnitude of the financial outcome of the company's activities before paying interest and repayment of the main amount of the loan. Then the function of distribution of probabilities of the financial outcome of an enterprise after the realization by them of the project of implementation of energy-saving technologies will take the following formalized form:

$$
\begin{aligned}
& P_{r e}\left(R_{e}\right)=
\end{aligned}
$$

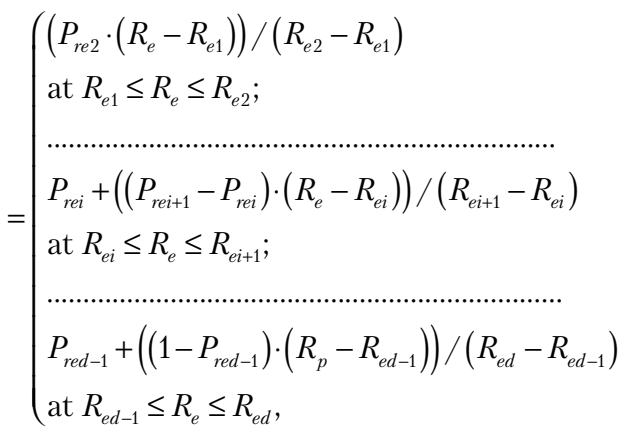

where $P_{r e}$ is the possibility that the magnitude of the financial outcome of the activity of an enterprise before paying interest and repaying the main loan amount after the project implementation will not exceed $R_{e}$;

$R_{e}$ is the variable magnitude that characterizes the financial outcome of the activity of an enterprise before payment of interest and repayment of the main amount of loan taken for project financing, monetary units;

$P_{r e i}$ is the probability that the magnitude of the financial outcome of the activity of an enterprise before payment of interest and repayment of the main amount of loan will not exceed $R_{e i}$ i

$d$ is the number of initial values of probability and corresponding magnitudes of the financial outcome of the activity of an enterprise before payment of interest and repayment of the main sum of loan.

If the function of distribution of probabilities of financial outcome for a project is presented in discrete form, the final set of values of this result and probabilities of these values are given. Note that by increasing the elements of such a set, it is always possible to obtain a set in which all values of financial outcome will have the same probability. This case will be considered below.

Consider the final set of non-negative values of the financial outcome for a project of implementation of energy-saving technologies at an enterprise. At the same time, 
financial outcome is determined before paying interest on the loan taken for the implementation of this project. The corresponding set will take the following form:

$$
M_{1}=\left\{R_{p m 1}, R_{p m 2}, \ldots, R_{p m i}, \ldots, R_{p m k-1}, R_{p m k}\right\},
$$

where $R_{p m i}$ is the financial outcome for a project before paying interest on the loan taken to implement the project in the $i$-th situation, monetary units;

$k$ is the total number of elements of the set (5).

Since the total number of elements of the set (5) is $k$, and by condition, all values of these elements have the same probability, this probability is $1 / k$.

Note that the set (5) must be ordered, namely, the values of its elements should not descend, that is, they must satisfy the following chain of inequalities:

$$
R_{p m 1} \leq R_{p m 2} \leq \ldots \leq R_{p m i} \leq \ldots \leq R_{p m k-1} \leq R_{p m k} .
$$

We will now introduce into consideration the second set, which is a derivative of set (5). In this new set, all elements except the first one will be the difference between the values of the next and the previous elements:

$$
\begin{aligned}
& M_{2}=\left\{\begin{array}{l}
R_{p m 1}, R_{p m 2}-R_{p m 1}, \ldots, \\
R_{p m i}-R_{p m i-1}, \ldots, R_{p m k}-R_{p m k-1}
\end{array}\right\}= \\
& =\left\{\Delta R_{p m 1}, \ldots, \Delta R_{p m i}, \ldots \Delta R_{p m k}\right\},
\end{aligned}
$$

where $\Delta R_{p m i}$ is the values of the $i$-th element of set (7), monetary units; in this case, the first elements of sets (5), (7) coincide.

Note that among the elements of set (7), there can be elements with zero values (if set (5) have the same elements). However, this circumstance does not affect the final results of the study.

Each element of the set (7) can be associated with a certain probabilistic characteristic. In particular, for the first element, it will be zero, and for the last $1 / k$. For the $i$-th element, this characteristic will be $1-(i-1) / k$. In fact, the considered characteristic describes the threat not to receive financial outcome $\Delta R_{p m i}$. With this in mind, the set (7) can be matched by two more sets, namely:

1. A set of values of mathematical expectation for each element of set (7):

$$
\begin{aligned}
& M_{3}=\left\{\begin{array}{l}
R_{p m 1},\left(R_{p m 2}-R_{p m 1}\right) \cdot(1-1 / k), \ldots, \\
\left(R_{p m i}-R_{p m i-1}\right\} \cdot(i-1) / k, \ldots, \\
\left(R_{p m k}-R_{p m k-1}\right) \cdot(k-1) / k
\end{array}\right\}= \\
& =\left\{M_{p m 1}, \ldots, M_{p m i}, \ldots M_{p m k}\right\},
\end{aligned}
$$

where $M_{p m i}$ is the value of the $i$-th element of set (8), monetary units.

2. A set of quotients of values of mathematical expectation for each element of the set (7) in the total magnitude of mathematical expectation for all elements of this set:

$$
M_{4}=\left\{\alpha_{1}, \ldots, \alpha_{i}, \ldots, \alpha_{k}\right\},
$$

where $\alpha_{i}$ is the value of the $i$-th element of set (9), which is found from the following formula:

$$
\alpha_{i}=\frac{\left(R_{p m i}-R_{p m i-1}\right\} \cdot(i-1) / k}{\sum_{i=1}^{k}\left(\left(R_{p m i}-R_{p m i-1}\right\} \cdot(i-1) / k\right)} .
$$

Then the level of risk of realization of the project for the implementation of energy-saving technologies by an enterprise can be estimated as the sum of products of probability of not gaining certain values of financial outcome $\Delta R_{p m i}$ and the values of the corresponding elements of the set (9):

$$
I_{R}=\sum_{i=1}^{k} \Delta R_{p m i} \cdot \alpha_{i}
$$

where $I_{R}$ is the level of risk of realization of the project for the implementation of energy-saving technologies by an enterprise.

The basic idea of constructing expression (11) is that the function of distributing the financial outcome of the project implementation is divided into separate elements (these are elements of set (7)). Each of these elements is matched to a certain level of probability that it will not be obtained as a result of the project implementation, that is, the level of risk for this element is determined. Then the total riskiness of the project will be equal to the weighted value of risk for all elements of set (7).

It should be noted that the magnitude of indicator (11) can gain values in the section from zero to unity. The closer it approaches the unity, the more risky a certain project should be considered.

5. 3. Methods for assessing the existing and prospective potential of loan financing of projects for implementing energy-saving technologies

Assessment of the existing potential of loan financing of projects of implementing energy-saving technologies at enterprises should include the following sequence of actions:

1. Formation of a sample of enterprises. In this case, if enterprises belong to different types of economic activity, samples should be formed for each of these types.

2. Formation of a set of projects of implementation of energy-saving technologies at the studied enterprises.

3. Creation of an array of input information necessary to assess the existing potential of loan financing of projects of implementation of energy-saving technologies at enterprises.

4. Separation in a set of projects for the implementation of energy-saving technologies at studied enterprises of a subset of those projects that should be financed through loans.

5. Calculation of the values of absolute and relative indicators of estimation of the existing potential of loan financing of projects for implementation of energy-saving technologies at enterprises.

As for the criteria for the selection of projects of implementation of energy-saving technologies at enterprises, the set of these criteria should correspond to the stages of project selection presented above in Fig. 1. In particular, it is possible to give the following form of the criterion of existence of a positive value of average expected profitability of a particular project:

$$
\frac{1}{I_{n v}} \cdot \sum_{i=1}^{k}\left(\frac{R_{p m i}}{k}\right)>0
$$

where $I_{n v}$ is the total magnitude of investment required to realize the project of implementation of energy-saving technologies, monetary units. 
Similarly, one can formalize the criterion of the existence of a permissible value of the average expected profitability of a particular project. This criterion will take the following form:

$$
\frac{1}{I_{n v}} \cdot \sum_{i=1}^{k}\left(\frac{R_{p m i}}{k}\right) \geq P_{r a \min },
$$

where $P_{\text {ramin }}$ is the minimum permissible, from the positions of owners and managers, level of profitability of investment in the realization of the project of implementation of energy-saving technologies.

The third criterion for the selection of projects should include separation of those, the implementation of which is not worthwhile postponing for the future. This criterion should be formalized as follows:

$$
\sum_{t=1}^{T} \frac{F_{t}}{(1+r)^{t}}+\frac{V_{n p T}}{(1+r)^{T}} \leq V_{n p 0} \text { for all } T,
$$

where $T$ is the interval of time from the given moment to the moment of changing existing technological processes for energy-saving technologies, years;

$F_{t}$ is the net cash flow (sum of profit and depreciation charges) on condition of using old technological processes in the $t$-th year, beginning with the given moment of time, monetary units;

$r$ is the annual discount rate for a certain project;

$V_{n p T}$ is the net current cost of the project of implementation of energy-saving technologies by the moment of the beginning of gaining income on it provided that this moment is $T$, monetary units.

The following criterion should ensure rejection of the projects, the implementation of which is more profitable to implement in advance at the expense of other sources (that is, not through loans). This criterion will be exceeding the need for investments in the project over the amount of funds that the company can attract on an irrevocable and free of charge basis.

The fifth criterion for the selection of projects should include rejecting those, the implementation of which cannot be carried out in advance through loan financing due to the unsatisfactory financial condition of enterprises that provide for such implementation. This criterion will be exceeding the need for investment in the project over the magnitude of the creditworthiness potential of the enterprise that plans to implement this project.

Regarding the separation of those projects for the implementation of energy-saving technologies, the financing of which from loan sources is economically beneficial for enterprises, this separation requires the application of at least two criteria. The first criterion is to ensure the proper relation between the average expected return on investment in a project and the loan interest rate. The second criterion will be the permissible level of probability that the financial outcome of a project after paying interest on the loan will be non-negative. These two criteria will take the following form:

$$
\begin{aligned}
& \frac{1}{I_{n v} \cdot r_{c}} \cdot \sum_{i=1}^{k}\left(\frac{R_{p m i}}{k}\right) \geq \beta ; \\
& P_{r p}\left(I_{n v} \cdot r_{c}\right) \leq P_{r 1},
\end{aligned}
$$

where $r_{c}$ is the annual interest rate on the loan;

$\beta$ is the minimum ratio of the average expected profitability of investment in the project to the percent of loan rate, admissible from the point of view of owners and managers of an enterprise;

$P_{r}$ is the minimum admissible level of probability that the financial outcome of a project after the payment of interest on the received loan will turn out to be non-negative.

It should be noted that the process of establishing the magnitude of $\beta$ coefficient can be deprived of subjectivism if the above formula (11) is used. To do this, follow this sequence of actions:

1. Form set (5). In this case, the restriction on the non-negativity of its elements is not imposed.

2. If in the formed set, there are elements with negative values, increase all its values by the modulo-taken value $R_{p m 1}$. Then get the adjusted set (5).

3. Determine the level of risk of a project by formula (11).

4. Evaluate the market value of the project, the financial outcomes of which are described by set (5) or adjusted set (5). With this purpose, mathematical expectation of financial outcomes is capitalized at a risk-free rate, followed by a decrease in the received magnitude in proportion to the level of project risk. In particular, in the case of the adjusted set (5), the corresponding calculation can be performed from the following formula:

$$
C_{p}=\frac{1}{r_{n r}} \cdot \sum_{i=1}^{k}\left(\frac{R_{p m i}+R_{p m 1}}{k}\right) \cdot\left(1-I_{R}\right),
$$

where $C_{p}$ is the market cost of a project, the financial cost of which is described by the adjusted set (5), monetary units;

$r_{n r}$ is the risk-free capitalization rate.

5 . Check the condition of the feasibility of loan financing of the implementation of the project, the financial results of which are described by set (5). This condition takes the following form:

$$
C_{p}-\frac{R_{p m 1}}{r_{n r}} \geq \frac{I_{n v} \cdot r_{c}}{r_{n r}}
$$

or

$$
\frac{1}{r_{n r}} \cdot \sum_{i=1}^{k}\left(\frac{R_{p m i}+R_{p m 1}}{k}\right) \cdot\left(1-I_{R}\right)-\frac{R_{p m 1}}{r_{n r}} \geq \frac{I_{n v} \cdot r_{c}}{r_{n r}} .
$$

From inequality (19), obtain:

$$
\beta=\frac{\sum_{i=1}^{k}\left(\frac{R_{p m i}}{k}\right)}{I_{n v} \cdot r_{c}}=\frac{1}{1-I_{R}} \cdot\left(1+\frac{R_{p m 1} \cdot I_{R}}{I_{n v} \cdot r_{c}}\right) .
$$

The seventh criterion for the selection of projects of energy-saving technologies to implement at enterprises should include the separation of the projects, the loan financing of which will not have a too negative impact on their financial stability. To formalize this criterion, the following condition for timely repayment of the taken loan should be presented:

$$
\sum_{t=1}^{T_{r}} \frac{F_{r}}{\left(1+r_{c}\right)^{t}}=\frac{F_{r}}{r_{c}} \cdot\left(1-\frac{1}{\left(1+r_{c}\right)^{T_{r}}}\right)=I_{n v},
$$

where $T_{r}$ is the total term of payment of the loan, taken by an enterprise, years; 
$F_{r}$ is the annual magnitude of costs directed to repay the loan, monetary units.

From equation (21), obtain:

$$
F_{r}=\frac{I_{n v} \cdot r_{c}}{1-\frac{1}{\left(1+r_{c}\right)^{T_{r}}}}
$$

Taking into consideration the above, the criterion for the separation of the projects, the loan financing of which will not have a too negative impact on the financial stability of enterprises will be as follows:

$$
P_{e p}\left(F_{r}\right) \leq P_{r 2},
$$

where $P_{r 2}$ is the maximum permissible level of probability that an enterprise will not be able to repay the full amount of the loan, obtained to finance the project of implementation of energy-saving technologies.

In the end, the criterion that the loan financing of an energy-saving project by an enterprise will not have a too negative impact on the volume of dividend payments can be formalized as follows:

$$
P_{e p}\left(F_{r}+D_{\min }\right) \leq P_{r 3},
$$

where $D_{\min }$ is the minimum admissible annual magnitude of dividend payments, from the point of view of the owner of an enterprise, monetary units.

$P_{r 3}$ is the maximum possible level of probability that an enterprise, having taken the loan to finance an energy-saving project, will not be able to ensure the minimum admissible level of dividend payments.

The issue of how fully enterprises use the existing potential of loan financing of projects for the implementation of energy-saving technologies is of certain interest. The following indicator can be used to assess the level of using this potential:

$$
I_{p c}=\frac{C_{f}-C_{n f}}{C_{p}},
$$

where $I_{p c}$ is the indicator of the assessment of the level of using the existing at enterprises potential of loan financing of projects for the implementation of energy-saving technologies;

$C_{f}$ is the actual amount of investments in these projects, financed by enterprises at the expense of borrowed sources, monetary units;

$C_{n f}$ is the actual amount of investment in the projects which were financed by loans, but this financing turned out to be inappropriate, monetary units;

$C_{h}$ is the estimated absolute magnitude of the potential of loan financing of projects for the implementation of energy-saving technologies, monetary units.

In order to predict the amount of loan financing of realization of projects of implementation of energy-saving technologies at enterprises in the future, it is worthwhile assessing not only existing but also the prospective potential of such financing. The sequence of assessment of this potential will include the following main stages:

1. Formation of a set of the projects, the loan financing of which was impractical when assessing the existing potential of loan financing of the implementation of energy-saving technologies by enterprises.
2. Separation of the factors, due to which it is possible to expect positive changes in the future among the factors that influence the need for loans to finance the implementation of energy-saving technologies at enterprises (Table 2).

3. Quantitative assessment and forecasting of positive changes of separated factors.

4. Establishment of the links between these changes and the set of projects, which will be worthwhile financing through loans, provided that these changes take place.

5. Calculation of the values of absolute and relative indicators of estimation of the prospective potential of loan financing of projects of implementation of energy-saving technologies at enterprises.

In particular, among the factors that have an impact on the economic effectiveness and feasibility of loan financing of projects, one of the central places is taken by the interest rate on a bank loan. A decrease in this rate may lead to a significant increase in the need for loan financing of projects of implementation of energy-saving technologies at enterprises.

Fig. 3 shows the sequence of assessing the prospective potential of loan financing of projects for the implementation of energy-saving technologies at enterprises, provided that the future interest rate on a bank loan decreases.

Expressions to determine the values of the loan interest rates that appear in Fig. 3 can be found by constructing certain equations and finding formulas for their solution relative to $r_{c}$.

In particular, to obtain a formula for determining magnitude $r_{c 1}$, it is necessary to convert inequality (19) into an equation. Then, having expressed $r_{c}$ from this equation, we get:

$$
r_{c 1}=\frac{1}{I_{n v}}\left(\frac{1}{r_{n r}} \cdot \sum_{i=1}^{k}\left(\frac{R_{p m i}+R_{p m 1}}{k}\right) \cdot\left(1-I_{R}\right)-R_{p m 1}\right),
$$

where $r_{c 2}$ is the sought-for value of the rate of loan interest rate, at which inequality (19) is converted into equality.

To find an expression to determine indicator $r_{c 2}$, it is worth considering function $Z$, which is inverse to the function (3). Then the sought-for expression is determined from the following equation:

$$
Z\left(P_{r 1}\right)=I_{n v} \cdot r_{c}
$$

From (27), we obtain:

$$
r_{c 2}=\frac{Z\left(P_{r 1}\right)}{I_{n v}}
$$

where $r_{c 2}$ is the sought-for value of the loan interest rate, at which equality (27) is true.

To find an expression to determine indicators $r_{c 3}$ and $r_{c 4}$ (Fig. 3), it is worth considering function $W$, which is inverse to function (4). Then the sought-for expressions are determined from the following equations:

$$
\begin{aligned}
& \frac{I_{n v} \cdot r_{c}}{1-\frac{1}{\left(1+r_{c}\right)^{T_{r}}}}=W\left(P_{r 2}\right) ; \\
& \frac{I_{n v} \cdot r_{c}}{1-\frac{1}{\left(1+r_{c}\right)^{T_{r}}}}=W\left(P_{r 3}\right)-D_{\min } .
\end{aligned}
$$


Division of the input set of projects of implementation of energy-saving technologies at enterprises into three sub-sets
Projects that are worthwhile financing by loans at existing interest rates
Projects that are not worthwhile financing by loans at any interest rates
Establishment of such loan interest rate for every project, at which its financing by loans will become profitable

\begin{tabular}{|c|c|c|c|}
\hline $\begin{array}{l}\text { Determining the } \\
\text { interest rate on loan } \\
r_{c 1} \text {, at which } \\
\text { appropriate ratio } \\
\text { between average } \\
\text { expected profitability } \\
\text { of investment in a } \\
\text { project and the } \\
\text { interest rate is } \\
\text { ensured }\end{array}$ & $\begin{array}{l}\text { Determining the } \\
\text { interest rate on } \\
\text { loan } r_{c 2} \text {, at which } \\
\text { the admissible } \\
\text { level of probability } \\
\text { that the financial } \\
\text { outcome under the } \\
\text { project after } \\
\text { paying the interest } \\
\text { on taken loan will } \\
\text { not appear } \\
\text { negative, is } \\
\text { ensured }\end{array}$ & $\begin{array}{l}\text { Determining the } \\
\text { interest rate on } \\
\text { loan } r_{c 3} \text {, at which } \\
\text { the admissible } \\
\text { level of probability } \\
\text { that loan financing } \\
\text { will not have the } \\
\text { negative impact on } \\
\text { the financial } \\
\text { stability of } \\
\text { enterprises, is } \\
\text { insured }\end{array}$ & $\begin{array}{l}\text { Determining the } \\
\text { interest rate on } \\
\text { loan } r_{c 4} \text {, at which } \\
\text { the admissible } \\
\text { level of probability } \\
\text { that the loan } \\
\text { financing will not } \\
\text { have too negative } \\
\text { impact on the } \\
\text { volume of } \\
\text { dividend payment, } \\
\text { is ensured }\end{array}$ \\
\hline$\downarrow$ & $\downarrow$ & $\downarrow$ & $\downarrow$ \\
\hline \multicolumn{4}{|c|}{ Determining the residual value of the sought-for rate $r_{c i}=\max \left\{r_{c 1}, r_{c 2}, r_{c 3}, r_{c 4}\right\}$} \\
\hline $\begin{array}{l}\text { Construction for all } \\
\text { projects which will b }\end{array}$ & $\begin{array}{r}\text { of projects of the } \\
\text { while financing b } \\
\text { such } \mathrm{f}\end{array}$ & $\begin{array}{l}\text { dence of the interes } \\
\text { 1s, as well as on the } \\
\text { ing }\end{array}$ & $\begin{array}{l}\text { e on the number of } \\
\text { imes of the need for }\end{array}$ \\
\hline
\end{tabular}

Fig. 3. The sequence of assessing the prospective potential of loan financing of projects for the implementation of energy-saving technologies at enterprises provided that the future interest rate on a bank loan is reduced

From the equations (29), (30) one can derive formulas for approximate calculation of indicators $r_{c 3}$ and $r_{c 4}$. In particular, if these values a priori are significantly smaller than unity, it is possible to be limited to the first three terms of the decomposition series of the power expression in formulas (29), (30). Then accordingly we get:

$$
\begin{aligned}
& r_{c 3} \approx 2 \cdot\left(\frac{W\left(P_{r 2}\right) \cdot T_{r}-I_{n v}}{W\left(P_{r 2}\right) \cdot T_{r}^{2}}\right) ; \\
& r_{c 3} \approx 2 \cdot\left(\frac{\left(W\left(P_{r 3}\right)-D_{\min }\right) \cdot T_{r}-I_{n v}}{\left(W\left(P_{r 3}\right)-D_{\min }\right) \cdot T_{r}^{2}}\right),
\end{aligned}
$$

where $r_{c 3}, r_{c 4}$ are the sought-for values of loan interest rate, at which equality (29) and equality (30) are true, respectively.

Expressions (26) to (32) can be applied when justifying state and municipal preferential lending programs for enterprises seeking to implement energy-saving projects.
Projects that are worthwhile financing by loans provided an interest rate is decreased
5. 4. Approbation of the obtained theoretic and methodological results

Many countries face the problem to reduce the consumption of non-renewable energy resources, in particular, natural gas. That is why the projects of implementation of the technologies that involve a reduction of specific consumption of natural gas at enterprises were analyzed. To this end, 100 enterprises of Ukraine were selected from three industries, for which significant consumption of natural gas is characteristic. These industries include manufacturing metal products, production of glass and glass products, as well as production of bricks, tiles, and other building materials made of clay.

73 out of 120 enterprises remained for further consideration after conducting a survey at them. Other enterprises did not provide sufficient information or did not consider the possibility of implementing projects to reduce natural gas consumption within 2019-2020.

Based on the collected information, we formed an array of input data that is necessary to assess the potential of loan financing of projects of implementation of technologies that reduce natural gas consumption at the studied enterprises. Information about the enterprises and projects for which this potential was evaluated is presented in Table 4.

Based on the processing of an array of collected information, we formed input data and calculated the absolute magnitude of the potential of loan financing by enterprises of projects of implementation of technologies that ensure a decrease in natural gas consumption. At the same time, in order to reject projects that are inappropriate to finance by loans, the above criteria were used. The corresponding calculations were carried out both by the number of relevant projects (Table 5 ) and by the volume of investments in their implementation (Table 6).

As follows from the data shown in Table 5, it is possible to mention three main reasons that caused the inappropriateness of loan financing of some projects for the introduction of technologies for reducing natural gas consumption at the enterprises under consideration. These reasons are the inadequate level of financial stability of enterprises (as a result, 10 projects were rejected), low credit effectiveness (12 projects were rejected), and its negative impact on the financial stability of enterprises (9 projects were rejected). In addition, 7 projects were not 
profitable enough to be implemented in general. Since the number of projects of reducing natural gas consumption at the studied enterprises, the implementation of which turned out to be impractical, is 52 , the four listed reasons explain $73 \%$ of those rejected. At the same time, as follows from the data shown in Table 6, the volume of necessary investments in these four groups of the rejected projects is respectively USD 330, 459, 651 and 386 thousand. Since the volume of the need for investments in all rejected projects amounted to USD 2,492 thousand, the four reasons listed above, account for $73.3 \%$ of the magnitude of these volumes. This almost corresponds to the case when the volume of project rejections was determined by their number.

Table 4

Data on enterprises and the projects of implementation of technologies that reduce natural gas consumption, for which the potential of loan financing was assessed

\begin{tabular}{|c|c|c|c|c|}
\hline \multirow[b]{2}{*}{ Indicators } & \multicolumn{3}{|c|}{ Values of indicators for the types of economic activity } & \multirow[b]{2}{*}{ Total } \\
\hline & $\begin{array}{c}\text { Manufacturing } \\
\text { products from metal }\end{array}$ & $\begin{array}{l}\text { Production of glass } \\
\text { and glass products }\end{array}$ & $\begin{array}{c}\text { Production of bricks, tiles, and } \\
\text { other building materials from clay }\end{array}$ & \\
\hline 1. Number of enterprises under consideration & 27 & 21 & 25 & 73 \\
\hline 2. Number of projects under consideration & 33 & 27 & 34 & 94 \\
\hline 3. Average number of projects per enterprise & 1.22 & 1.29 & 1.36 & 1.29 \\
\hline $\begin{array}{l}\text { 4. Total amount of investments required for the } \\
\text { implementation of all projects, USD thousand }\end{array}$ & 1,664 & 1,287 & 1,346 & 4297 \\
\hline 5. Average investment per project, USD thousand & 50.42 & 47.67 & 39.59 & 45.71 \\
\hline
\end{tabular}

Table 5

Input data and results of calculation of the absolute magnitude of existing potential of loan financing of projects of implementation of technologies that reduce natural gas consumption by the number of projects

\begin{tabular}{|c|c|c|c|c|}
\hline \multirow[b]{2}{*}{ Indicators } & \multicolumn{3}{|c|}{ Values of indicators for the kinds of economic activity } & \multirow[b]{2}{*}{ Total } \\
\hline & $\begin{array}{l}\text { Manufacturing } \\
\text { products from } \\
\text { metal }\end{array}$ & $\begin{array}{l}\text { Production of } \\
\text { glass and glass } \\
\text { products }\end{array}$ & $\begin{array}{l}\text { Production of bricks, tiles, and } \\
\text { other building materials from } \\
\text { clay }\end{array}$ & \\
\hline 1. Number of projects under consideration & 33 & 27 & 34 & 94 \\
\hline $\begin{array}{l}\text { 2. Including projects: } \\
\text { 2.1. With negative or zero average expected profitability }\end{array}$ & 2 & 1 & 2 & 5 \\
\hline 2. 2. With too low average expected profitability & 3 & 2 & 2 & 7 \\
\hline $\begin{array}{l}\text { 2.3. Implementation of which should be postponed for the } \\
\text { future }\end{array}$ & 1 & 0 & 1 & 2 \\
\hline $\begin{array}{l}\text { 2. 4. Loan financing of which is impractical to do in } \\
\text { advance }\end{array}$ & 0 & 0 & 0 & 0 \\
\hline $\begin{array}{l}\text { 2. 5. Those that cannot be financed through loans at the } \\
\text { current level of financial stability of enterprises }\end{array}$ & 4 & 3 & 3 & 10 \\
\hline $\begin{array}{l}\text { 2. 6. Financing which at the expense of loan sources is not } \\
\text { economically profitable for enterprises }\end{array}$ & 3 & 4 & 5 & 12 \\
\hline $\begin{array}{l}\text { 2. 7. Loan financing of which will have a too negative } \\
\text { impact on the financial stability of enterprises }\end{array}$ & 3 & 2 & 4 & 9 \\
\hline $\begin{array}{l}\text { 2. 8. Loan financing of which will have a too negative } \\
\text { impact on the volume of dividend payments }\end{array}$ & 2 & 2 & 3 & 7 \\
\hline $\begin{array}{l}\text { 3. Total number of projects that are worthwhile imple- } \\
\text { menting through loan financing }\end{array}$ & 15 & 13 & 14 & 42 \\
\hline
\end{tabular}

Table 6

Output data and results of calculation of the absolute magnitude of existing potential of loan financing of projects for implementation of technologies that reduce natural gas consumption according to investment volumes

\begin{tabular}{|c|c|c|c|c|}
\hline \multirow[b]{2}{*}{ Indicators } & \multicolumn{3}{|c|}{ Values of indicators by the types of economic activity } & \multirow[b]{2}{*}{ Total } \\
\hline & $\begin{array}{c}\text { Manufacturing } \\
\text { products from metal }\end{array}$ & $\begin{array}{l}\text { Production of glass } \\
\text { and glass products }\end{array}$ & $\begin{array}{c}\text { Production of bricks, tiles, and } \\
\text { other building materials from clay }\end{array}$ & \\
\hline 1 & 2 & 3 & 4 & 5 \\
\hline $\begin{array}{l}\text { 1. Total volume of investment required to imple- } \\
\text { ment all projects, thousand UAH }\end{array}$ & 1,664 & 1,287 & 1,346 & 4,297 \\
\hline $\begin{array}{l}\text { 2. Including the volumes of investment in projects: } \\
\text { 2. 1. With negative and zero average expected } \\
\text { profitability }\end{array}$ & 73 & 52 & 103 & 228 \\
\hline 2. 2. With too low average expected profitability & 119 & 124 & 87 & 330 \\
\hline $\begin{array}{l}\text { 2. 3. Implementation of which is advisable to post- } \\
\text { pone for the future }\end{array}$ & 54 & 39 & 45 & 138 \\
\hline $\begin{array}{l}\text { 2. 4. Loan financing of which is not advisable to do } \\
\text { in advance }\end{array}$ & 0 & 0 & 0 & 0 \\
\hline
\end{tabular}


Continuation of Table 6

\begin{tabular}{|c|c|c|c|c|}
\hline 1 & 2 & 3 & 4 & 5 \\
\hline $\begin{array}{l}\text { 2. 5. Those that can not be financed by loans at the } \\
\text { existing level of financial stability of enterprises }\end{array}$ & 243 & 109 & 107 & 459 \\
\hline $\begin{array}{l}\text { 2. 6. Financing of which from borrowed sources is } \\
\text { not economically profitable for an enterprise }\end{array}$ & 133 & 275 & 243 & 651 \\
\hline $\begin{array}{l}\text { 2.7. Loan financing of which will make too negative } \\
\text { influence on the financial stability of enterprises }\end{array}$ & 176 & 74 & 136 & 386 \\
\hline $\begin{array}{l}\text { 2. 8. Loan financing of which will make too nega- } \\
\text { tive influence on volumes of dividend payments }\end{array}$ & 87 & 94 & 119 & 300 \\
\hline $\begin{array}{l}\text { 3. Total volume of required investment in the projects } \\
\text { that are advisable to implement by loan financing }\end{array}$ & 779 & 520 & 506 & 1805 \\
\hline
\end{tabular}

Thus, according to the data shown in Tables 5, 6, the absolute magnitude of the potential of loan financing of projects of reducing natural gas consumption is 42 projects and USD 1,805 thousand. As for the relative level of this potential, in the whole totality of enterprises it is: by the number of projects 0.447 (42/94); by volumes of financing - 0.420 (1805/4297). As for similar estimates in terms of the types of economic activity, the graphic interpretation of these estimates is shown in Fig. 4.

Fig. 4 shows that the relative level of the potential of loan financing of projects of reducing natural gas consumption at

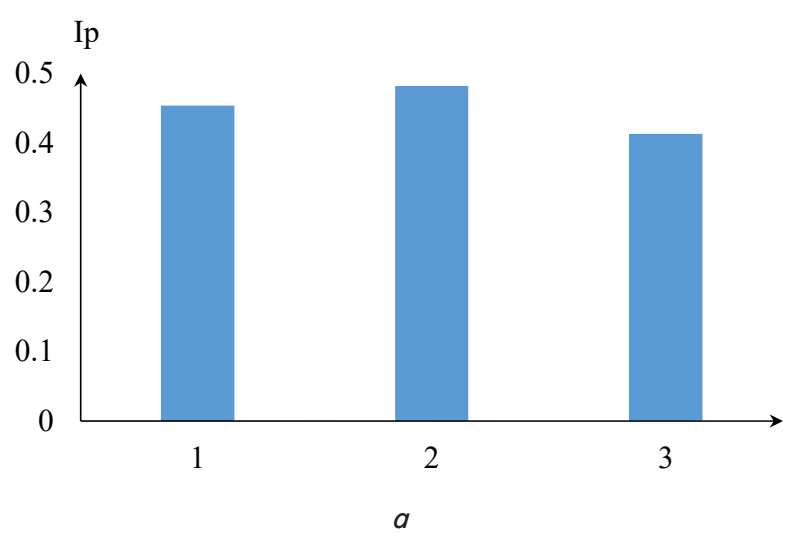

the enterprises under study differs slightly depending on the industry in which these enterprises operate. In particular, the enterprises that produce bricks, tiles, and other building materials made of clay have the lowest level. However, the differences in the values of the assessed indicator do not exceed $20 \%$.

Based on the data given in Tables 5, 6, it is possible, for instance, to calculate the values of indicators contained in the multiple models (1) and (2). The results of these calculations are shown in Table 7.

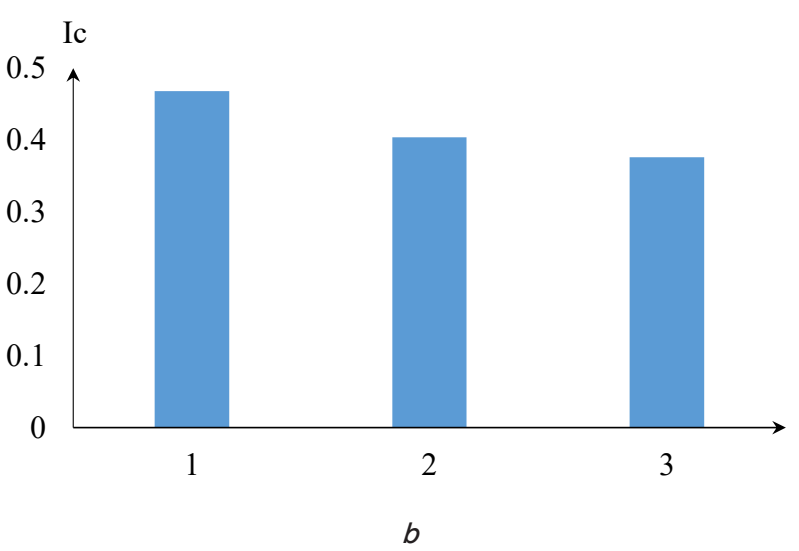

Fig. 4. Indicators of the relative level of the potential of loan financing of projects of reducing natural gas consumption at the enterprises under study: $a$ - by the number of projects; $b$ - in terms of volumes of financing, where $1-$ production of metal products; 2 - production of glass and glass products; 3 - manufacture of bricks, tiles and other building materials from clay

Table 7

Values of indicators contained in multiplicative models of the magnitude of the relative level of existing potential of loan financing of projects for the implementation of energy-saving technologies at enterprises

\begin{tabular}{|c|c|c|c|c|c|c|c|c|}
\hline \multirow{3}{*}{ Indicators } & \multicolumn{6}{|c|}{ Values of indicators for the kinds of economic activity } & \multirow{2}{*}{\multicolumn{2}{|c|}{ Total }} \\
\hline & \multicolumn{2}{|c|}{$\begin{array}{c}\text { Manufacturing prod- } \\
\text { ucts from metal }\end{array}$} & \multicolumn{2}{|c|}{$\begin{array}{l}\text { Production of glass } \\
\text { and glass products }\end{array}$} & \multicolumn{2}{|c|}{\begin{tabular}{|c|} 
Production of bricks, \\
tiles, and other build- \\
ing materials from clay \\
\end{tabular}} & & \\
\hline & \begin{tabular}{|c|} 
By \\
number of \\
projects
\end{tabular} & $\begin{array}{c}\text { By volume } \\
\text { of invest- } \\
\text { ment }\end{array}$ & \begin{tabular}{c|} 
By \\
number of \\
projects
\end{tabular} & \begin{tabular}{|c|} 
By volume \\
of invest- \\
ment
\end{tabular} & \begin{tabular}{|c|}
$\begin{array}{c}\text { By num- } \\
\text { ber of } \\
\text { projects }\end{array}$ \\
\end{tabular} & $\begin{array}{c}\text { By volume } \\
\text { of invest- } \\
\text { ment }\end{array}$ & $\begin{array}{l}\text { By num- } \\
\text { ber of } \\
\text { projects }\end{array}$ & $\begin{array}{c}\text { By volume } \\
\text { of invest- } \\
\text { ment }\end{array}$ \\
\hline 1 & 2 & 3 & 4 & 5 & 6 & 7 & 8 & 9 \\
\hline 1. Share of profitable projects among all projects & 0.939 & 0.956 & 0.963 & 0.960 & 0.941 & 0.923 & 0.947 & 0.947 \\
\hline $\begin{array}{l}\text { 2. Share of projects with permissible average } \\
\text { profitability among profitable projects }\end{array}$ & 0.903 & 0.925 & 0.923 & 0.900 & 0.938 & 0.930 & 0.921 & 0.919 \\
\hline $\begin{array}{l}\text { 3. Share of projects, the implementation of } \\
\text { which is not advisable to postpone, among } \\
\text { projects with permissible average profitability }\end{array}$ & 0.964 & 0.963 & 1.000 & 0.965 & 0.967 & 0.961 & 0.976 & 0.963 \\
\hline $\begin{array}{l}\text { 4. Share of projects that may be appropriate } \\
\text { to finance from borrowed sources, among } \\
\text { projects, the implementation of which is not } \\
\text { advisable to postpone }\end{array}$ & 1.000 & 1.000 & 1.000 & 1.000 & 1.000 & 1.000 & 1.000 & 1.000 \\
\hline
\end{tabular}


Continuation of Table 7

\begin{tabular}{|c|c|c|c|c|c|c|c|c|}
\hline 1 & 2 & 3 & 4 & 5 & 6 & 7 & 8 & 9 \\
\hline $\begin{array}{l}\text { 5. Share of projects, to finance which enterpris- } \\
\text { es are able to attract loans at the current level } \\
\text { of their financial stability, among projects that } \\
\text { may be appropriate to finance from loan sources }\end{array}$ & 0.852 & 0.829 & 0.875 & 0.898 & 0.897 & 0.904 & 0.875 & 0.873 \\
\hline $\begin{array}{l}\text { 6. Share of projects, financing of which from } \\
\text { loan sources is economically beneficial for } \\
\text { enterprises, among projects, to finance which } \\
\text { enterprises are able to attract loans at the } \\
\text { existing level of their financial stability }\end{array}$ & 0.870 & 0.887 & 0.810 & 0.714 & 0.808 & 0.758 & 0.829 & 0.793 \\
\hline $\begin{array}{l}\text { 7. Share of projects, loan financing will not } \\
\text { have a too negative impact on changing the } \\
\text { financial stability of enterprises, among proj- } \\
\text { ects, financing of which from loan sources is } \\
\text { economically profitable for enterprises }\end{array}$ & 0.850 & 0.831 & 0.882 & 0.892 & 0.810 & 0.821 & 0.845 & 0.845 \\
\hline \begin{tabular}{|l|} 
8. Share of projects, financing of which by \\
loans will not have a too negative impact on \\
the volume of dividend payments of enterpris- \\
es, among projects financing of which by loans \\
will not have a too negative impact on chang- \\
ing the financial stability of enterprises \\
\end{tabular} & 0.882 & 0.900 & 0.867 & 0.847 & 0.824 & 0.810 & 0.857 & 0.857 \\
\hline
\end{tabular}

As follows from the data shown in Table 7, among the calculated indicators for the entire totality of projects, the share of projects, financing of which from borrowed sources is economically beneficial for enterprises is the lowest. The value of this share by the number of projects is 0.829 , and by the amount of financing is 0.793 . If these values were equal to unity, the relative level of the potential of loan financing would be $0.539(0.447 / 0.829)$ and $0.530(0.420 / 0.793)$, respectively.

Using expression (25), it is possible to estimate the level of using the existing potential of loan financing of projects for the implementation of technologies for reducing natural gas consumption at the enterprises under study. The input and results of this level assessment are shown in Table 8 .
As follows from the data in Table 8, the value of the indicator of assessment of the level of using the potential of loan financing of projects for the implementation of energy-saving technologies existing at the enterprises under study is on average 0.766 . At the same time, the magnitude of this indicator by type of economic activity ranges from 0.721 to 0.837 . Thus, at least some of the enterprises under study did not fully use the potential of loan financing of projects for the implementation of energy-saving technologies. The reason for this is the lack of competence of the owners and managers of these enterprises in matters of loan financing of energy-saving projects.

Using models (26) to (32), it is possible to calculate the predicted increase in the potential of loan financing of energy-saving projects at the studied

Table 8

Input data and results of the assessment of the level of using the existing potential of loan financing of the projects of implementation of technologies that reduce natural gas consumption at the enterprises under study

\begin{tabular}{|l|c|c|c|c|}
\hline \multirow{2}{*}{\multicolumn{1}{|c|}{ Indicators }} & \multicolumn{2}{|c|}{$\begin{array}{r}\text { Values of indicators for the kinds of } \\
\text { economic activity }\end{array}$} & \\
\cline { 2 - 4 } & $\begin{array}{c}\text { Manu- } \\
\text { facturing } \\
\text { products } \\
\text { from metal }\end{array}$ & $\begin{array}{c}\text { Production } \\
\text { of glass } \\
\text { and glass } \\
\text { products }\end{array}$ & $\begin{array}{c}\text { Production of } \\
\text { bricks, tiles, and } \\
\text { other building } \\
\text { materials from } \\
\text { clay }\end{array}$ & Total \\
\hline $\begin{array}{l}\text { 1. The estimated absolute magnitude of } \\
\text { potential of loan financing of projects for } \\
\text { implementation of energy-saving technol- } \\
\text { ogies, USD thousand }\end{array}$ & 779 & 520 & 506 & 1,805 \\
\hline $\begin{array}{l}\text { 2. Actual amount of investments in } \\
\text { projects financed by enterprises from } \\
\text { borrowed sources, USD thousand }\end{array}$ & 562 & 435 & 386 & 1,483 \\
\hline $\begin{array}{l}\text { 3. Actual amount of investments in the } \\
\text { projects, which were financed by loans, } \\
\text { but this financing turned out to be im- } \\
\text { practical, USD thousand }\end{array}$ & 0 & 0 & 0 & 0 \\
\hline $\begin{array}{l}\text { 4. Indicator of assessment of the level of } \\
\text { using the existing enterprising potential } \\
\text { of loan financing of projects for the imple- } \\
\text { mentation of energy-saving technologies }\end{array}$ & 0.721 & 0.837 & 0.763 & 0.766 \\
\hline
\end{tabular}

enterprises by reducing the loan interest rate. A graphical image of the results of these calculations is shown in Fig. 5.

Comparison of the information given in Fig. 5 with the data of $\mathrm{Ta}$ ble 5 shows that at a fairly low loan interest rate, it becomes advisable to implement a number of previously rejected projects of reducing natural gas consumption. However, then this rate should be from $2 \%$ to $4 \%$ per year. That is why in order to increase the scope of the introduction of technologies for reducing natural gas consumption, state authorities need to increase the availability of preferential lending programs for those enterprises that seek to realize such implementation. At the same time, it is worth considering a decrease in the preferential credit interest rate to $2-4 \%$ for enterprises that will implement the projects of saving the imported types of energy resources. 


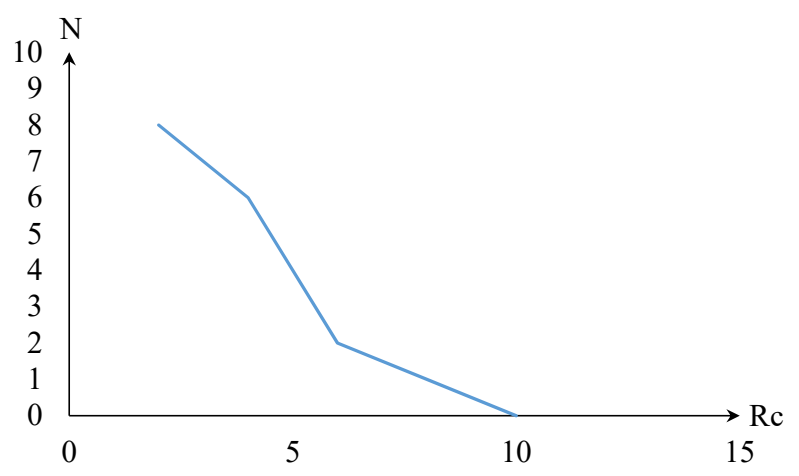

$a$
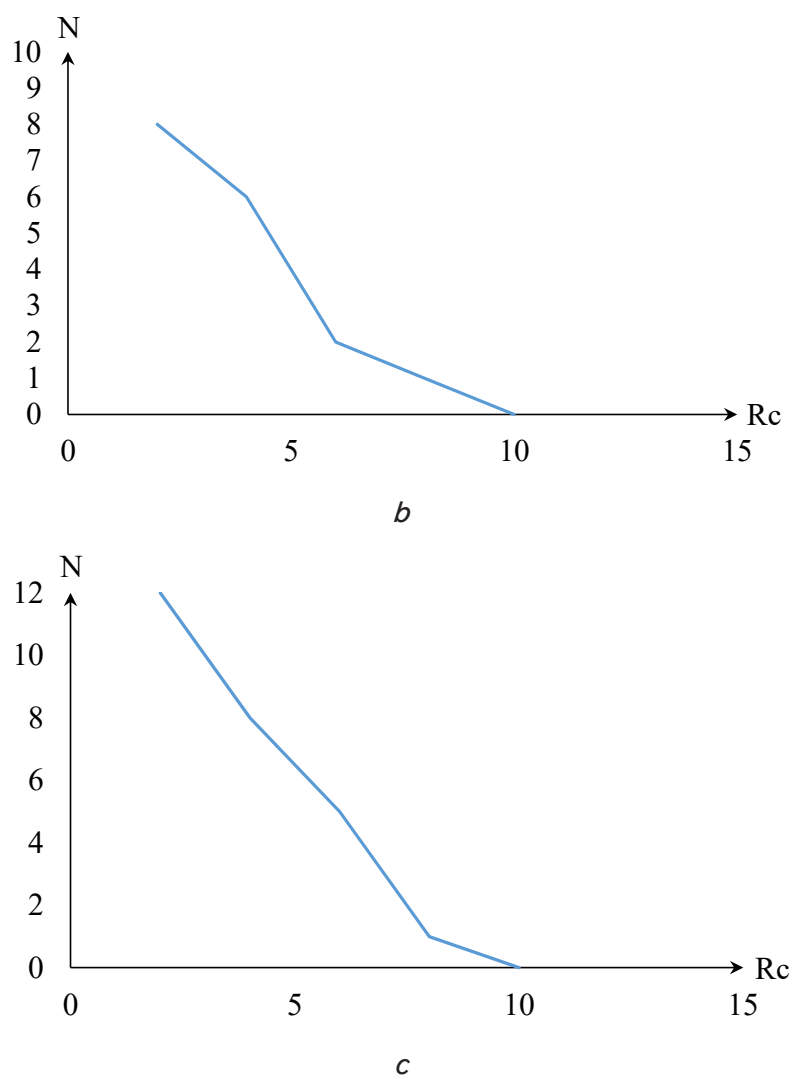

Fig. 5. The additional number of projects of reducing natural gas consumption ( $M$ ) that could be implemented by the studied enterprises if the annual loan interest rate would be $R_{c}, \%: a-$ for enterprises producing metal products; $b-$ for enterprises producing glass and glass products; $c-$ for enterprises producing brick, tile and other building materials made of clay

\section{Discussion of the devised toolset to assess the} potential of loan financing of projects for implementing energy-saving technologies

The conducted study showed that the process of assessing the potential of loan financing of the projects for the implementation of energy-saving technologies is complex and multi-stage. At the same time, only a part of the input set of such projects may ultimately be recognized as suitable for loan financing. The obtained results are explained by the fact that there is a whole set of criteria that must be met for the energy-saving projects that can be implemented through a bank loan and other borrowed sources of financing. These criteria must be properly formalized and organized.

The obtained results of this study are a certain contribution to the overall developments that will facilitate solving the problem of assessing the potential of loan financing of projects for the implementation of energy-saving technologies. In particular, it became possible to provide a quantitative assessment of the absolute and relative potential of loan financing of projects for the implementation of energy-saving technologies. This opportunity emerged due to the formalization of the process of selection of those projects for the implementation of energy-saving technologies, which should be financed from borrowed sources of funds. In turn, the indicators of relative potential are presented in the form of multiplicative models. The use of these models makes it possible to identify and quantify the factors that have the most negative impact on the relative level of the potential of loan financing of projects for the implementation of energy-saving technologies.

Special attention in the research is paid to the formation of an information array to assess the potential of loan financing of projects of the implementation of energy-saving technologies. Based on the grouping of input information required for such evaluation shown in Table 3, the part of it that requires the use of special methods of formalization was separated. In particular, such methods include the construction of discrete and continuous functions of distribution of probabilities of financial outcomes under projects of the implementation of energy-saving technologies, as well as the assessment of riskiness of these projects. To solve the last task, an essentially new indicator of project riskiness, which is calculated from formula (11), was developed. This indicator does not involve direct measurement of the level of dispersion of a random magnitude (financial results), that is, it is not identical to the coefficient of variation according to mean square deviation of a random magnitude. At the same time, this metric can gain the maximum value equal to unity, while the maximum value of the variable factor is generally not limited.

In accordance with the proposed sequence of the process of selection of projects for the implementation of energy-saving technologies, which should be financed from borrowed sources of funds, the criteria for such selection were established. In modern scientific literature, in general, many criteria for assessing the effectiveness and feasibility of loan financing of projects were presented. However, in this study, these criteria are properly organized and formalized. In addition, some of them, specifically, criterion (19), are new and universal enough, that is, they can be used to solve various tasks of project analysis. The main idea then will be to capitalize on financial outcomes of projects at a risk-free rate, followed by a decrease in the received magnitude in proportion to the project risk level calculated according to formula (11).

Approbation of the obtained theoretical and methodological results for the sample of enterprises showed the possibility of the practical application of these results. Collected and processed data shown in Tables 4-8 and Fig. 4, 5 must be recognized as sufficiently reliable and objective. At the same time, the obtained empirical results, which are relative in nature, are quite close to each other in the types of studied economic activity. This concerns, in particular, the indicator of assessment of the level of using the existing potential of loan financing of projects for the implementation of ener- 
gy-saving technologies. The value of this indicator according to the type of economic activity ranges from 0.721 to 0.837 . Thus, at least some of the enterprises under study did not fully use the potential of loan financing of projects for the implementation of energy-saving technologies.

Thus, the obtained theoretical and methodological results can be applied by enterprises of all types of economic activity in assessing the value of the potential of loan financing of energy-saving projects. In addition, these results can be used by state and local governments in the development of preferential lending programs for the realization of projects for the implementation of energy-saving technologies by enterprises.

At the same time, certain limitations are inherent in this study. In particular, only the case of full financing of energy-saving projects at the expense of loans was considered. However, it is possible that borrowed funds occupy only a certain share of the structure of project funding sources. The case when the loan interest rate and other lending conditions are known in advance was also considered. At the same time, it is possible that enterprises have the opportunity to choose creditors, taking into consideration the loan conditions offered by each of them.

In addition, certain shortcomings of the performed studies in this research are that the influence of factors on the magnitude of the potential of loan financing of projects for the implementation of energy-saving technologies was partially analyzed. In other words, the level of formalization and approbation of the model, which is presented in Fig. 2, is not high enough. In fact, among the impact factors, such formalization is performed only for the loan interest rate.

Formalization of the influence of the factors on the magnitude of the potential of loan financing of projects for the implementation of energy-saving technologies and approbation of the results of such formalization should be considered as promising areas for subsequent research on the topic of this work. However, there may be difficulties with collecting empirical data along the way, as information on some of these factors is difficult to obtain from open data sources.

\section{Conclusion}

1. Assessment of the potential of loan financing of projects for the implementation of energy-saving technologies requires, first of all, data on such projects. In the future, the projects that should be financed by bank loans and other types of loan sources of funds should be chosen among such projects. However, it is quite a complicated problem to select the projects that should be financed through loans in the input array of information about the projects of implementing energy-saving technologies. The solution to this problem requires the implementation of the multi-step process proposed in the research, which involves the implementation of actions to reject projects that do not meet the sequence of predefined criteria. At the same time, it is important not only to assess the potential of loan financing of projects for the implementation of energy-saving technologies but also to establish reserves for the growth of this potential. The solution to this problem will be facilitated by the use of multiplicative models of the relative level of the estimated potential. In addition, for this purpose, it is worth applying the proposed model of the influence of factors on the relative level of the potential of loan financing of projects for the implementation of energy-saving technologies.

2. Assessment of the potential of loan financing of projects of implementation of energy-saving technologies at enterprises requires a wide array of incoming (primary) information. This information can be divided into several units. In particular, it is worth highlighting information about the energy-saving project, expected financial outcomes of an enterprise after the project implementation, lending conditions, preferences of owners and managers, as well as other information. One of the main components of input information necessary to assess the potential of loan financing of projects for the implementation of energy-saving technologies is the functions of distribution of probabilities of financial outcomes. It is necessary to separate two main types of such functions - those describing financial outcomes of a project and those describing financial outcomes of an enterprise after the project implementation. The methods for representing the functions of distribution of probabilities of financial outcomes (in particular, by approximating the graphs of these functions with broken lines), proposed in the research, can significantly facilitate the process of their construction. It is also important to assess the degree of compliance with the proper ratio of the expected profitability of investment in an energy-saving project, which is supposed to be financed by loans, to the rate of the loan interest rate. To this end, it is worth using the project risk indicator proposed in the work.

3. In general, eight sequential criteria for the selection of the projects of the implementation of energy-saving technologies at enterprises that should be loan financed should be identified. Some of these criteria characterize only a project itself (in particular, the proper level of its profitability), while others also take into consideration the financial and economic state of the enterprise planning a project. At the same time, the proposed criteria can be used to assess not only the existing but also the prospective potential of loan financing of energy-saving projects. However, the assessment of perspective potential requires forecasting the changes in factors that affect the attractiveness of loan sources for enterprises to finance projects for the implementation of energy-saving technologies.

4. The absolute magnitude of the potential of loan financing of projects of the introduction of technologies for reducing natural gas consumption at the studied enterprises is 42 projects and USD 1,805 thousand. As for the relative level of this potential, in the whole totality of enterprises it is: by the number of projects -0.447 ; by volumes of financing -0.420 . It is possible to mention three main reasons that caused the inappropriateness of loan financing of some projects for the implementation of technologies that reduce the consumption of natural gas at the enterprises under study. These reasons are the inadequate level of financial stability of enterprises (as a result of this, 10 projects were rejected), low credit effectiveness (12 projects were rejected), and its negative influence on the financial stability of enterprises ( 9 projects were rejected). In addition, 7 projects were not profitable enough to be implemented in general. Since the number of projects to reduce natural gas consumption at the studied enterprises, the implementation of which turned out to be impractical is 52 , the four reasons listed explain $73 \%$ of the rejections. However, at a fairly low credit interest rate, it becomes advisable to implement a number of previously rejected projects for reducing natural gas consumption. However, for this purpose, this rate 
should be from $2 \%$ to $4 \%$ per year. That is why in order to increase the scale of the introduction of technologies that reduce natural gas consumption, state authorities should increase the availability of preferential lending programs for enterprises seeking to realize such implementation. At the same time, it is worth considering reducing the preferential credit interest rate to $2-4 \%$ for enterprises that will implement projects of saving the imported types of energy resources.

\section{References}

1. Bleischwitz, R., Andersen, L.-M. (2009). Informational Barriers to Energy Efficiency - Theory and European Policies. MPRA Paper No. 19937. Munich Personal RePEc Archive. Available at: https://mpra.ub.uni-muenchen.de/19937/1/MPRA_paper_19937.pdf

2. Zhang, Z., Jin, X., Yang, Q., Zhang, Y. (2013). An empirical study on the institutional factors of energy conservation and emissions reduction: Evidence from listed companies in China. Energy Policy, 57, 36-42. doi: https://doi.org/10.1016/j.enpol.2012.07.011

3. Tsurkan, M., Andreeva, S., Lyubarskaya, M., Chekalin, V., Lapushinskaya, G. (2017). Organizational and financial mechanisms for implementation of the projects in the field of increasing the energy efficiency of the regional economy. Problems and Perspectives in Management, 15 (3), 453-466. doi: https://doi.org/10.21511/ppm.15(3-2).2017.13

4. Jude, F. A., Adamou, N. (2018). Bank Loan Financing Decisions of Small and Medium-Sized Enterprises: The Significance of Owner/ Managers' Behaviours. International Journal of Economics and Finance, 10 (5), 231. doi: https://doi.org/10.5539/ijef.v10n5p231

5. Steeves, B. B., Ouriques, H. R. (2016). Energy Security: China and the United States and the Divergence in Renewable Energy. Contexto Internacional, 38 (2), 643-662. doi: https://doi.org/10.1590/s0102-8529.2016380200006

6. Absalamovich, N. B. (2020). Research on the use of alternative energy sources in Uzbekistan: Problems and prospects. ACADEMICIA: An International Multidisciplinary Research Journal, 10 (11), 763-768. doi: https://doi.org/10.5958/ 2249-7137.2020.01429.9

7. Yemelyanov, O., Petrushka, T., Symak, A., Trevoho, O., Turylo, A., Kurylo, O. et. al. (2020). Microcredits for Sustainable Development of Small Ukrainian Enterprises: Efficiency, Accessibility, and Government Contribution. Sustainability, 12 (15), 6184. doi: https://doi.org/10.3390/su12156184

8. Rostamkalaei, A., Freel, M. (2015). The cost of growth: small firms and the pricing of bank loans. Small Business Economics, 46 (2), 255-272. doi: https://doi.org/10.1007/s11187-015-9681-x

9. Yang, W. (2018). Empirical Study on Effect of Credit Constraints on Productivity of Firms in Growth Enterprise Market of China. Journal of Finance and Economics, 6 (5), 173-177. Available at: http://pubs.sciepub.com/jfe/6/5/2/index.html

10. Lin, Y., Li, L. (2018). Empirical Analysis of Microcredit in Western China: Based on Empirical Analysis. J. Chongqing Technol. Bus. Univ., 5 (1). Available at: https://en.cnki.com.cn/Article_en/CJFDTotal-CQYZ201805001.htm

11. Akinleye, G. T., Olarewaju, O. O. (2019). Credit Management and Profitability Growth in Nigerian Manufacturing Firms. Acta Universitatis Danubius, 15 (2), 445-456. Available at: http://journals.univ-danubius.ro/index.php/oeconomica/article/ view/5281/5232

12. Gill, A. S., Mand, H. S., Sharma, S. P., Mathur, N. (2012). Factors that Influence Financial Leverage of Small Business Firms in India. International Journal of Economics and Finance, 4 (3). doi: https://doi.org/10.5539/ijef.v4n3p33

13. Javed, Z. H., Rao, H. H., Akram, B., Nazir, M. F. (2015). Effect of Financial Leverage on Performance of the Firms: Empirical Evidence from Pakistan. SPOUDAI Journal of Economics and Business, 65 (1-2), 87-95. Available at: https://econpapers.repec.org/ article/spdjournl/v_3a65_3ay_3a2015_3ai_3a1-2_3ap_3a87-95.htm

14. Hoque, A. (2017). Impact of financial leverage on financial performance: Evidence from textile sector of Bangladesh. IIUC Business Review, 6, 75-84. Available at: http://dspace.iiuc.ac.bd:8080/xmlui/bitstream/handle/88203/687/IIUC-Business-Review-Vol-6Dec-2017-05.pdf?sequence=1\&isAllowed $=\mathrm{y}$

15. Adenugba, A. A., Ige, A. A., Kesinro, O. R. (2016). Financial leverage and firms' value: A study of selected firms in Nigeria. European Journal of Research and Reflection in Management Sciences, 4 (1), 14-32. Available at: https://www.idpublications.org/wpcontent/uploads/2016/01/Full-Paper-FINANCIAL-LEVERAGE-AND-FIRMS'-VALUE-A-STUDY-OF-SELECTED-FIRMSIN-NIGERIA.pdf

16. Agarwal, S., Chomsisengphet, S., Driscoll, J. C. (2004). Loan Commitments and Private Firms. SSRN Electronic Journal. doi: https:// doi.org/10.2139/ssrn.593862

17. Choi, S., Furceri, D., Huang, Y., Loungani, P. (2018). Aggregate uncertainty and sectoral productivity growth: The role of credit constraints. Journal of International Money and Finance, 88, 314-330. doi: https://doi.org/10.1016/j.jimonfin.2017.07.016

18. Lesinskyi, V., Yemelyanov, O., Zarytska, O., Symak, A., Koleshchuk, O. (2018). Substantiation of projects that account for risk in the resource-saving technological changes at enterprises. Eastern-European Journal of Enterprise Technologies, 6 (1 (96)), 6-16. doi: https://doi.org/10.15587/1729-4061.2018.149942

19. Angori, G., Aristei, D. (2018). A Panel Data Analysis of Firms' Access to Credit in the Euro Area: Endogenous Selection, Individual Heterogeneity and Time Persistence. SSRN Electronic Journal. doi: https://doi.org/10.2139/ssrn.3254358

20. Bhalli, M. T., Hashmi, S. M., Majeed, A. (2017). Impact of Credit Constraints on Firms Growth: A Case Study of Manufacturing Sector of Pakistan. Journal of Quantitative Methods, 1 (1), 4-40. doi: https://doi.org/10.29145/2017/jqm/010102

21. Krasniqi, B. A. (2010). Are small firms really credit constrained? Empirical evidence from Kosova. International Entrepreneurship and Management Journal, 6 (4), 459-479. doi: https://doi.org/10.1007/s11365-010-0135-2 
22. Dong, J., Huo, H. (2017). Identification of Financing Barriers to Energy Efficiency in Small and Medium-Sized Enterprises by Integrating the Fuzzy Delphi and Fuzzy DEMATEL Approaches. Energies, 10 (8), 1172. doi: https://doi.org/10.3390/en10081172

23. Malakhov, V. A. (2012). Assessing the economic effect from introduction of energy-saving technologies in the field of heat supply. Thermal Engineering, 59 (3), 250-257. doi: https://doi.org/10.1134/s0040601512030093

24. Weron, R. (2014). Electricity price forecasting: A review of the state-of-the-art with a look into the future. International Journal of Forecasting, 30 (4), 1030-1081. doi: https://doi.org/10.1016/j.ijforecast.2014.08.008

25. Yemelyanov, O., Symak, A., Petrushka, T., Lesyk, R., Lesyk, L. (2018). Evaluation of the Adaptability of the Ukrainian Economy to Changes in Prices for Energy Carriers and to Energy Market Risks. Energies, 11 (12), 3529. doi: https://doi.org/10.3390/ en11123529

26. Yemelyanov, O., Symak, A., Petrushka, T., Zahoretska, O., Kusiy, M., Lesyk, R., Lesyk, L. (2019). Changes in Energy Consumption, Economic Growth and Aspirations for Energy Independence: Sectoral Analysis of Uses of Natural Gas in Ukrainian Economy. Energies, 12 (24), 4724. doi: https://doi.org/10.3390/en12244724

27. Lesinskyi, V., Yemelyanov, O., Zarytska, O., Symak, A., Petrushka, T. (2020). Development of a toolkit for assessing and overcoming barriers to the implementation of energy saving projects. Eastern-European Journal of Enterprise Technologies, 5 (3 (107)), 24-38. doi: https://doi.org/10.15587/1729-4061.2020.214997

28. Hui, J., Cai, W., Wang, C., Ye, M. (2017). Analyzing the penetration barriers of clean generation technologies in China's power sector using a multi-region optimization model. Applied Energy, 185, 1809-1820. doi: https://doi.org/10.1016/j.apenergy.2016.02.034

29. Yemelyanov, O., Petrushka, T., Lesyk, L., Symak, A., Vovk, O. (2020). Modelling and Information Support for the Development of Government Programs to Increase the Accessibility of Small Business Lending. 2020 IEEE 15th International Conference on Computer Sciences and Information Technologies (CSIT). doi: https://doi.org/10.1109/csit49958.2020.9322040

30. Gaspar, J. dos S., Marques, A. C., Fuinhas, J. A. (2017). The traditional energy-growth nexus: A comparison between sustainable development and economic growth approaches. Ecological Indicators, 75, 286-296. doi: https://doi.org/10.1016/ j.ecolind.2016.12.048

31. Jaramillo, J. A., Sossa, J. W., Mendoza, J. L. O. (2019). Barriers to sustainability for small and medium enterprises in the framework of sustainable development - L iterature review. Business Strategy and the Environment, 28 (4), 512-524. doi: https:// doi.org/10.1002/bse.2261

32. Yemelyanov, O., Symak, A., Petrushka, T., Lesyk, R., Lesyk, L. (2018). Assessment of the Technological Changes Impact on the Sustainability of State Security System of Ukraine. Sustainability, 10 (4), 1186. doi: https://doi.org/10.3390/su10041186

33. Bylander, M., Res, P., Jacoby, L., Bradley, P., Pérez, A. B. (2019). Over-indebtedness and microcredit in Cambodia: Moving beyond borrower-centric frames. Development Policy Review, 37 (S2), O140-O160. doi: https://doi.org/10.1111/dpr.12399

34. Ewanchuk, L., Frei, C. (2019). Recent Regulation in Credit Risk Management: A Statistical Framework. Risks, 7 (2), 40. doi: https:// doi.org/10.3390/risks7020040

35. Nesbakken, R. (1999). Price sensitivity of residential energy consumption in Norway. Energy Economics, 21 (6), 493-515. doi: https:// doi.org/10.1016/s0140-9883(99)00022-5

36. Trianni, A., Cagno, E.,Worrell, E. (2013). Innovation and adoption of energy efficient technologies: An exploratory analysis of Italian primary metal manufacturing SMEs. Energy Policy, 61, 430-440. doi: https://doi.org/10.1016/j.enpol.2013.06.034 